\title{
The Role of Conjugated Linoleic Acid in Breast Cancer Growth and Development
}

\author{
Danielle L. Amarù, Patricia D. Biondo and Catherine J. Field*
}

Alberta Institute for Human Nutrition, Department of Agricultural, Food and Nutritional Science, University of Alberta, Edmonton, Alberta, Canada, T6G 2P5

\begin{abstract}
Conjugated linoleic acid (CLA) consists of a group of naturally occurring and synthetic positional and geometric (cis-trans) stereoisomers of the polyunsaturated fatty acid linoleic acid. The cis-9,trans-11 (c9,t11) CLA isomer (the most prevalent form found in ruminant-derived foods) and the trans-10,cis-12 (t10,c12) CLA isomer (present in commercial preparations) are the two most widely studied CLA isomers in breast cancer. Studies using both animal and cell culture models indicate that these CLA isomers, when added to the diet or included in the cell culture medium, inhibit mammary tumour initiation, promotion and progression in rodents, and alter tumour cell viability in vitro. The mechanism of CLA's anticancer effect is not well understood, but may involve interference with the cell cycle, induction of apoptosis, modulation of gene expression via the activation of peroxisome proliferator-activated receptors, lipid peroxidation, modulation of the tumour microenvironment, changes to the structure and/or function of the cell membrane, and interference with growth factor receptor signaling. A greater understanding of the mechanism of action of CLA will support the development of clinical trials to evaluate the potential effectiveness of CLA in the treatment of breast cancer.
\end{abstract}

Keywords: Breast cancer, conjugated linoleic acid, mammary, mechanisms, tumour.

\section{INTRODUCTION}

The pioneering work of Dr. T.K. Basu at the University of Alberta, Edmonton, Canada has demonstrated that both classical nutrients such Vitamin B-6 [1], niacin [2] and fiber [3] and isolated phytochemicals such as echinacea [4] and fenugreek [5] can have health benefits in the treatment and prevention of chronic and acute diseases. In 1981, Doll et al. estimated that $30 \%$ of all cancers could be prevented by dietary factors [6]. Epidemiological and animal studies support the hypothesis that nutritional factors play an important role in the etiology of breast cancer $[7,8]$. There is a growing interest in the potential role of neutraceuticals as these 'nutritional factors' that might have efficacy in both the prevention and treatment of cancer. In 1979, Pariza et al. discovered an anti-carcinogenic property of fried ground beef [9]. By 1987, the compound was isolated and identified as a polyunsaturated fatty acid (PUFA) called conjugated linoleic acid (CLA) [10]. Since then, numerous animal and cell culture studies have demonstrated that CLA may protect against breast cancer. The remainder of this review will describe what is currently known about the anti-carcinogenic properties of CLA in breast cancer and potential mechanisms for its anti-cancer properties.

\section{Conjugated Linoleic Acid (CLA)}

CLA consists of a group of positional and geometric (cis-trans) stereoisomers of linoleic acid (LA) that are

*Address correspondence to this author at the Department of Agricultural, Food and Nutritional Science, University of Alberta, 4-126A HRIF East, Edmonton, Alberta, Canada T6G 2E1; Tel: (780) 492-2597; Fax: (780) 4922011; E-mail: Catherine.Field@ualberta.ca commercially synthesized from plant oils [11] or formed during the biohydrogenation of LA to stearic acid by ruminant animals [12]. The cis-9, trans-11 (c9,t11) CLA isomer is the most prevalent form found in ruminant-derived foods (e.g. milk and meat) [12]. The trans-10,cis-12 (t10,c12) CLA isomer is present only in trace amounts in animal foods but is found in an approximate 50:50 ratio with c9,t11 CLA in commercial CLA preparations [12].

There are varying estimates in the literature as to the current average intake of CLA by the general population in westernized countries, ranging from 95 to $430 \mathrm{mg}$ per day [13-16]. These estimates are complicated by the variability of CLA content in food sources due to differences in feeding practices and inter-animal differences which affect the production of CLA in the rumen and mammary gland [17]. This variability in the food supply has made it challenging to study the intake of CLA in the general population and its effect on health.

\section{Human Studies Of CLA and Breast Cancer}

To date there have been no clinical trials in humans to test the effects of CLA on breast cancer prevention or treatment. The only human data available is from epidemiological studies. Five such studies have examined the relationship between CLA intake and risk of breast cancer (Table 1). The results of these studies are conflicting: both an increased and decreased risk of breast cancer have been reported for CLA consumption. The epidemiological studies may be limited by the variability of CLA in the food supply as well as the difficulty of assessing the intake of this minor dietary component. 
Table 1. Epidemiological Studies of CLA and Breast Cancer Risk

\begin{tabular}{|l|l|l|}
\hline Reference & Type of Study & Results \\
\hline \hline$[108]$ & Case control (Finland) & $\begin{array}{l}0.4 \text { odds ratio for breast cancer for highest quintile of CLA intake }(\sim 200 \mathrm{mg} / \mathrm{d}) \\
\text { in postmenopausal women }\end{array}$ \\
\hline$[109]$ & Cohort (Netherlands) & Positive trend for highest quintile of c9,t11 CLA intake $(\sim 290 \mathrm{mg} / \mathrm{d})$ \\
\hline$[110]$ & Case control (USA) & $\begin{array}{l}\text { Slight protective effect at highest intake of c9,t11 CLA in estrogen receptor negative } \\
\text { breast cancer in premenopausal women }\end{array}$ \\
\hline$[111]$ & Case control (France) & $\begin{array}{l}\text { No change in risk for metastasis using CLA content in breast adipose } \\
\text { tissue obtained during surgery }\end{array}$ \\
\hline$[112]$ & Cohort (Sweden) & No significant association between dietary CLA intake and risk of breast cancer \\
\hline
\end{tabular}

\section{Animal Studies of CLA and Mammary Cancer}

Numerous studies using various animal models support the hypothesis that both synthetic and naturally enriched sources of CLA added to the diet inhibit mammary tumour initiation [18-34], promotion and progression [35-41] in rodents (Table 2 ). A range of $0.1 \%$ to $1 \% \mathrm{w} / \mathrm{w}$ of CLA, independent of the level and type of fat in the diet, has shown to be effective, with no further benefits beyond $1 \% \mathrm{w} / \mathrm{w}$ $[19,24]$. The stage at which CLA is introduced in the diet appears to impact its effectiveness. When Ip et al. [20] provided CLA solely during mammary development prior to the injection of carcinogen, the protection against mammary cancer continued for the duration of the study even though CLA was no longer in the diet. In contrast, if CLA was introduced in the diet after mammary development, its intake had to be continuous for the remainder of the experiment to confer a protective effect [20]. In contrast to the majority of animal studies, no effect on tumour growth was observed with the injection of WAZ-2T mammary cancer cells into a mouse model. Furthermore, the t10,c12 CLA isomer was shown to increase initiation rate and lung metastasis, although not survival time, in a transgenic mouse overexpressing the growth receptor ErbB2 [42, 43]. CLA has been shown to dramatically alter fat deposition and body weight in mice [44]. Thus, the transgenic mouse model effects may have been due to changes to the stroma (which consists partly of adipocytes) surrounding the cells rather than the epithelial cells themselves [43].

\section{Cell Culture Studies of CLA and Breast Cancer}

Consistent with the in vivo results, CLA provided as individual isomers, a 50:50 mixture of c9,t11 CLA and t10,c12 CLA, or as CLA-enhanced milk fat decreases the growth, viability and/or increases death in a variety of breast cancer cell lines as reviewed in Table 3. Effectiveness has ranged from 10-200 $\mu \mathrm{M}$, which falls within the concentrations of CLA that have been observed in human serum $(10-350 \mu \mathrm{M})$, including among people taking CLA supplements long-term [45].

Some studies have provided CLA as a free fatty acid in ethanol, whereas others conjugated CLA to the carrier protein albumin. Free fatty acids are toxic to cells and desBordes and Lea [46] showed that by increasing the albumin to fatty acid ratio there was a decrease in the inhibitory effect of CLA. This difference in supply of fatty acids may explain why some studies were able to see inhibition at lower concentrations of CLA than others.

\section{POTENTIAL MECHANISMS OF CYTOTOXICITY OF CLA ISOMERS TO BREAST CANCER CELLS}

\section{Interference with the Cell Cycle}

CLA treatment of breast cancer cell lines has been reported to interfere with progression of the cell cycle. Studies in human breast cancer cell lines have shown an accumulation of cells in the G0/G1 (resting/growth) phase along with a corresponding decrease in the mRNA or protein expression of cell cycle promoters (e.g. c-myc, cyclin D1) and increased mRNA or protein expression of negative cell cycle regulators (p53, p21 $\left.{ }^{\mathrm{Cip} 1 / \mathrm{WAF} 1}, \mathrm{p} 27\right)$ with CLA treatment [47-51]. The t10,c12 CLA isomer was more effective at inhibiting proliferation than $\mathrm{c} 9, \mathrm{t} 11 \mathrm{CLA}$ in the MCF-7 breast cancer cell line [48].

\section{Induction of Apoptosis}

CLA treatment is reported to increase apoptosis in human and rodent mammary cancer cells [25, 51-56]. Some of the observed changes consistent with the induction of apoptosis include: increased wild-type p53 protein levels, chromatin condensation, increased pro-apoptotic bax and bak protein levels, reduced anti-apoptotic bcl-2 protein levels, increased cytochrome $\mathrm{c}$ in the cytosol, and increased cleavage of initiator and effector caspases, reduced COX-2 activity and the generation of $\mathrm{PGE}_{2}[25,51,52,54-57]$. A recent report indicated that $\mathrm{t} 10, \mathrm{c} 12$ CLA induces apoptosis in TM4t mammary tumour cells using certain components of the endoplasmic reticulum (ER) stress response, an alternative pathway to apoptosis in addition to the classical death receptor ("extrinsic") or mitochondrial ("intrinsic") pathways [53]. The mechanism of CLA-induced ER stress was proposed to involve increased lipid peroxidation products among CLAtreated cells [53].

\section{Activation of Peroxisome Proliferator-Activated Receptors}

Peroxisome proliferator-activated receptors (PPARs) are nuclear hormone receptors that have been implicated in multiple cell processes including regulation of the cell cycle 
Table 2. Animal Studies of CLA and Mammary Cancer

\begin{tabular}{|c|c|c|c|c|c|c|}
\hline Reference & Animal Model & Tumour & Basal Diet & CLA Content & Results & Mechanism Tested \\
\hline$[18]$ & $\begin{array}{l}\text { Female } \\
\text { Sprague- } \\
\text { Dawley } \\
\text { rats }\end{array}$ & $\begin{array}{l}\text { DMBA- } \\
\text { induced }\end{array}$ & AIN-76A & $\begin{array}{l}0.25,0.5,1,1.5 \% \mathrm{w} / \mathrm{w} \\
\text { CLA (synthetic source: } 43 \% \\
\mathrm{c} 9, \mathrm{t} 11 \text { and } \mathrm{t} 9, \mathrm{c} 11,45 \% \\
\mathrm{t} 10, \mathrm{c} 12 \text { ), fed } 2 \text { wks prior to } \\
\text { DMBA administration } \\
\text { until termination }\end{array}$ & $\begin{array}{l}\text { CLA } \downarrow \text { number and size of } \\
\text { tumours }\end{array}$ & $\begin{array}{l}\text { Only c9,t1 } 1 \text { CLA was incorporated } \\
\text { into mammary tumour and liver PL } \\
\text { CLA } \downarrow \text { lipid peroxidation in the } \\
\text { mammary gland but not the liver; } \\
\text { maximal antioxidant activity } \\
\text { occurred with } 0.25 \% \text { CLA, whereas } \\
\text { maximal tumour suppression } \\
\text { occurred with } 1 \% \text { CLA, suggesting } \\
\text { another mechanism besides lipid } \\
\text { peroxidation } \\
\text { No change to estrus cycle }\end{array}$ \\
\hline [19] & $\begin{array}{l}\text { Weanling } \\
\text { female Sprague- } \\
\text { Dawley rats }\end{array}$ & $\begin{array}{l}\text { Experiment 1: } \\
\text { DMBA- } \\
\text { induced } \\
\text { Experiment 2: } \\
\text { DMBA- or } \\
\text { NMU-induced }\end{array}$ & AIN-76A & $\begin{array}{l}\text { Experiment 1: } 0.05,0.1,0.25 \text {, } \\
0.5 \% \text { w/w CLA (synthetic } \\
\text { source: } 43 \% \mathrm{c} 9, \mathrm{t} 11 \text { and } \mathrm{t} 9, \mathrm{c} 11 \text {, } \\
45 \% \mathrm{t} 10, \mathrm{c} 12 \text { ), fed } 2 \text { wks prior } \\
\text { to DMBA administration until } \\
\text { termination } \\
\text { Experiment } 2: 1 \% \mathrm{w} / \mathrm{w} \text { CLA } \\
\text { fed for } 5 \text { wks (from weaning } \\
\text { until } 1 \text { wk post-DMBA } \\
\text { administration) }\end{array}$ & $\begin{array}{l}\text { Experiment } 1 \text { : CLA } \downarrow \text { total } \\
\text { mammary tumour yield in } \\
\text { a dose-dependent manner } \\
\text { from } 0.05 \text { to } 0.5 \% \text { CLA; as } \\
\text { little as } 0.1 \% \text { CLA signifi- } \\
\text { cantly } \downarrow \text { tumour number } \\
\text { Experiment } 2: 1 \% \text { CLA } \\
\text { significantly } \downarrow \text { mammary } \\
\text { tumour yield in both } \\
\text { DMBA and NMU tumour } \\
\text { models }\end{array}$ & $\begin{array}{l}1 \% \text { CLA } \downarrow \text { proliferation of the } \\
\text { lobuloalveolar compartment of the } \\
\text { mammary tree }\end{array}$ \\
\hline$[20]$ & $\begin{array}{l}\text { Female Spra- } \\
\text { gue-Dawley rats }\end{array}$ & NMU-induced & $\begin{array}{l}\text { Modified } \\
\text { AIN-76A }\end{array}$ & $\begin{array}{l}1 \% \text { w/w CLA (synthetic FFA } \\
\text { vs. TG) fed from } 21 \text { to } 42 \mathrm{~d} \text { of } \\
\text { age, or } 1 \% \text { CLA fed post- } \\
\text { NMU (injected at } 56 \mathrm{~d} \text { of age) } \\
\text { for } 1 \text { month, } 2 \text { months, or } \\
\text { continuously }\end{array}$ & $\begin{array}{l}\text { Both FFA and TG forms } \\
\text { of CLA } \downarrow \text { tumour number } \\
\text { and incidence }\end{array}$ & $\begin{array}{l}\text { Continuous feeding was required for } \\
\text { maximal inhibition of tumourigenesis } \\
\text { when CLA feeding was started after } \\
\text { NMU injection to derive the same } \\
\text { benefit as CLA feeding during the } \\
\text { early post-weaning and pubertal } \\
\text { period only }\end{array}$ \\
\hline [21] & $\begin{array}{l}\text { Sprague- } \\
\text { Dawley rats }\end{array}$ & $\begin{array}{l}\text { DMBA- } \\
\text { induced }\end{array}$ & $\begin{array}{l}\text { AIN- } 76: 10- \\
20 \% \mathrm{w} / \mathrm{w} \\
\text { vegetable fat } \\
\text { blend, or } \\
20 \% \text { corn oil, } \\
\text { or } 8 \% \text { corn } \\
\text { oil }+12 \% \\
\text { lard }\end{array}$ & $\begin{array}{l}1 \% \mathrm{w} / \mathrm{w} \text { CLA, or } 20 \% \text { corn oil } \\
\text { and } 0.5,1.0 \text { or } 1.5 \% \mathrm{w} / \mathrm{w} \text { CLA }\end{array}$ & $\begin{array}{l}\text { CLA } \downarrow \text { tumour incidence } \\
\text { by } 50 \% \text {, independent of } \\
\text { level or type of fat in diet } \\
\text { Maximal inhibition was } \\
\text { seen at } 1 \% \mathrm{w} / \mathrm{w} \text { CLA }\end{array}$ & $\begin{array}{l}\text { CLA } \downarrow \text { lipid peroxidation } \\
\text { (malondialdehyde) in mammary } \\
\text { gland homogenate } \\
\text { Cell oxidative stress } \\
\text { (8-hydroxydeoxy-guanosine) } \\
\text { was unaffected by CLA }\end{array}$ \\
\hline$[35]$ & SCID mice & $\begin{array}{l}\text { MDA-MB- } \\
468 \text { cells }\end{array}$ & N/A & $\begin{array}{l}1 \% \mathrm{w} / \mathrm{w} \text { CLA mix (synthetic } \\
\text { source: } 42 \% \mathrm{c} 9, \mathrm{t} 11,44 \% \\
\text { t10,c12), fed } 2 \text { wks prior to } \\
\text { tumour cell injection until } \\
\text { termination }\end{array}$ & $\begin{array}{l}\text { CLA } \downarrow \text { tumour mass and } \\
\text { metastases }\end{array}$ & $\begin{array}{l}\text { CLA works independently of the } \\
\text { immune system }\end{array}$ \\
\hline$[42]$ & $\begin{array}{l}\text { Eight wk-old } \\
\text { female BALB/c } \\
\text { mice }\end{array}$ & WAZ-2T cells & $\begin{array}{l}5 \% \text { fat }(4.1 \% \\
\text { corn oil })\end{array}$ & $\begin{array}{l}0.1,0.3,0.9 \% \text { CLA (derived } \\
\text { from safflower oil: } 35 \% \mathrm{c} 9, \mathrm{t} 11 \text {, } \\
39 \% \mathrm{t} 10, \mathrm{c} 12 \text { ), fed } 2 \mathrm{wks} \text { prior } \\
\text { to tumour injection until } \\
\text { termination }\end{array}$ & $\begin{array}{l}\text { CLA did not affect tumour } \\
\text { volume, incidence or } \\
\text { latency }\end{array}$ & $\begin{array}{l}\text { CLA } \uparrow \text { lymphocyte maturity } \\
\text { (blastogenesis) and } \uparrow \text { IL-2 } \\
\text { production, but did not affect } \\
\text { mammary tumour lipid } \\
\text { peroxidation activity }\end{array}$ \\
\hline$[22]$ & $\begin{array}{l}\text { Female } \\
\text { Sprague- } \\
\text { Dawley rats }\end{array}$ & $\begin{array}{l}\text { DMBA- } \\
\text { induced }\end{array}$ & $20 \%$ corn oil & $\begin{array}{l}1 \% \text { CLA, fed post-DMBA for } \\
4 \text { or } 8 \text { wks or continuously }\end{array}$ & $\begin{array}{l}\text { Only CLA fed } \\
\text { continuously significantly } \\
\downarrow \text { tumour growth }\end{array}$ & $\begin{array}{l}\text { Inhibition was not dependent on ras } \\
\text { CLA was retained faster and } \\
\text { in greater amounts in neutral } \\
\text { lipids vs. PL in the mammary } \\
\text { gland }\end{array}$ \\
\hline
\end{tabular}


Table 2. contd...

\begin{tabular}{|c|c|c|c|c|c|c|}
\hline Reference & Animal Model & Tumour & Basal Diet & CLA Content & Results & Mechanism Tested \\
\hline [23] & $\begin{array}{l}\text { Female Sprague } \\
\text { Dawley rats }\end{array}$ & $\begin{array}{l}\text { DMBA- } \\
\text { induced }\end{array}$ & AIN-76A & $\begin{array}{l}1 \% \mathrm{w} / \mathrm{w} \text { CLA fed from wean- } \\
\text { ing to } 50 \mathrm{~d} \text {, or from } 55 \mathrm{~d} \text { to } \\
\text { termination, or from weaning } \\
\text { to termination }\end{array}$ & $\begin{array}{l}\text { CLA } \downarrow \text { the total number of } \\
\text { tumours by } 50 \%\end{array}$ & $\begin{array}{l}\text { CLA } \downarrow \text { the density of mammary } \\
\text { epithelium branching, } \downarrow \text { DNA } \\
\text { synthesis in terminal end buds and } \\
\text { lobuloalveolar buds, and } \uparrow \text { CLA } \\
\text { metabolites (18:3 and 20:3) in the } \\
\text { mammary gland } \\
\text { CLA had no effect on fat deposition } \\
\text { in the mammary gland }\end{array}$ \\
\hline [113] & $\begin{array}{l}\text { Female Fischer } \\
\text { F344 rats }\end{array}$ & PhIP-induced & $\begin{array}{l}\text { AIN-76A } \\
\text { minus } \\
\text { antioxidants }\end{array}$ & $\begin{array}{l}0.1,0.5 \text { or } 1 \% \mathrm{w} / \mathrm{w} \text { CLA } \\
\text { (synthetic source), fed from } 4 \\
\text { wks of age for } 8 \mathrm{wks}\end{array}$ & Not reported & $\begin{array}{l}\text { CLA inhibited PhIP-DNA adduct } \\
\text { formation in the liver and white } \\
\text { blood cells but not in mammary or } \\
\text { colon epithelial cells } \\
\text { CLA did not affect cytochrome } \\
\text { P450 1A1 or 1A2 mRNA levels in } \\
\text { the liver }\end{array}$ \\
\hline$[24]$ & $\begin{array}{l}\text { Female } \\
\text { Sprague- } \\
\text { Dawley } \\
\text { rats }\end{array}$ & NMU-induced & AIN-76A & $\begin{array}{l}0.5,1,1.5 \% \text { or } 2 \% \mathrm{w} / \mathrm{w} \text { CLA } \\
\text { fed from weaning until NMU } \\
\text { injection, then fed basal diet } \\
\text { until termination }\end{array}$ & $\begin{array}{l}\text { CLA } \downarrow \text { the number and } \\
\text { incidence of tumours in a } \\
\text { dose-dependent manner } \\
\text { from } 0.5 \text { to } 1 \% \text { CLA; no } \\
\text { further benefit detected } \\
\text { above } 1 \% \text { CLA }\end{array}$ & $\begin{array}{l}\text { CLA } \downarrow \text { terminal end bud density in } \\
\text { the mammary gland in a dose- } \\
\text { dependent manner from } 0.5 \text { to } 1 \% \\
\text { CLA; no further benefit detected } \\
\text { above } 1 \% \text { CLA } \\
\text { CLA and CLA metabolites accumu- } \\
\text { lated in mammary tissue dose- } \\
\text { dependently from } 0.5 \% \text { to } 2 \% \text { CLA } \\
\text { CLA did not affect LA accumulation } \\
\text { but did } \downarrow \text { LA metabolites, in particu- } \\
\text { lar AA, in mammary gland }\end{array}$ \\
\hline$[25]$ & $\begin{array}{l}\text { Female } \\
\text { Sprague- } \\
\text { Dawley rats }\end{array}$ & NMU-induced & $\begin{array}{l}\text { AIN-76- } \\
\text { based with } \\
20 \% \mathrm{w} / \mathrm{w} \\
\text { control butter } \\
\text { fat }\end{array}$ & $\begin{array}{l}20 \% \mathrm{w} / \mathrm{w} \text { high CLA butter fat } \\
\text { (providing } 0.8 \% \mathrm{w} / \mathrm{w} \text { CLA), or } \\
20 \% \mathrm{w} / \mathrm{w} \text { control butter fat }+ \\
0.7 \% \text { Matreya CLA ( } 81 \% \\
\text { c } 9, \mathrm{t} 11) \text {, or } 20 \% \mathrm{w} / \mathrm{w} \text { control } \\
\text { butter fat }+0.7 \% \text { Nu-chek } \\
\text { CLA ( } 36.5 \% \text { t10,c12, } 25.3 \% \\
\text { c9,t1 } 1 \text { ), fed from weaning until } \\
\text { NMU injection, then fed a } 5 \% \\
\text { corn oil diet without CLA }\end{array}$ & $\begin{array}{l}\text { All CLA treatments } \downarrow \text { the } \\
\text { number and incidence of } \\
\text { tumours by } \sim 50 \%\end{array}$ & $\begin{array}{l}\text { CLA } \downarrow \text { mammary epithelial } \\
\text { branching, } \downarrow \text { terminal end bud } \\
\text { density and } \downarrow \text { proliferative activity } \\
\text { of terminal end buds } \\
\text { Rats consuming the CLA-enriched } \\
\text { butter fat consistently accumulated } \\
\text { more CLA in the mammary gland } \\
\text { and other tissues than those animals } \\
\text { consuming synthetic free fatty acid } \\
\text { CLA }\end{array}$ \\
\hline [26] & $\begin{array}{l}\text { Female } \\
\text { Sprague- } \\
\text { Dawley rats }\end{array}$ & NMU-induced & AIN-76A & $\begin{array}{l}1 \% \mathrm{c} 9, \mathrm{t} 11 \mathrm{CLA} \text { or } \\
1 \% \text { CLA mix }(36.5 \% \mathrm{t} 10, \mathrm{c} 12, \\
25.3 \% \mathrm{c} 9, \mathrm{t} 11,17.6 \% 11,13, \\
15.3 \% 8,10)\end{array}$ & $\begin{array}{l}\text { c9,t11 CLA and CLA mix } \\
\downarrow \text { the number of premali- } \\
\text { gnant intraductal prolifera- } \\
\text { tions by } 50 \%\end{array}$ & $\begin{array}{l}\text { c9,t11 CLA and CLA mix } \uparrow \\
\text { apoptosis and } \downarrow \text { bcl-2 expression in } \\
\text { premalignant lesions, but did not } \\
\text { affect bak or bax } \\
\text { CLA did not induce apoptosis in } \\
\text { normal mammary gland alveoli or } \\
\text { terminal end buds }\end{array}$ \\
\hline [36] & $\begin{array}{l}\text { Female } \\
\text { BALB/cAnN } \\
\text { mice }\end{array}$ & $\begin{array}{l}\text { Mouse } \\
\text { mammary } \\
\text { tumour cell } \\
\text { line } 4526\end{array}$ & $\begin{array}{l}\text { Semi purified } \\
\text { diet with } 20 \% \\
\text { w/w fat } \\
\text { (mostly corn } \\
\text { oil) }\end{array}$ & $\begin{array}{l}0.1 \%, 0.5 \% \text {, or } 1 \% \mathrm{w} / \mathrm{w} \\
\text { CLA mix }\end{array}$ & $\begin{array}{l}0.5 \% \text { and } 1 \% \text { CLA } \uparrow \\
\text { tumour latency time and } \downarrow \\
\text { lung metastases } \\
\text { No significant inhibition of } \\
\text { growth }\end{array}$ & $\begin{array}{l}\text { Indomethacin was more effective at } \\
\text { inhibition than CLA }\end{array}$ \\
\hline [27] & $\begin{array}{l}\text { Female F344 } \\
\text { rats }\end{array}$ & $\begin{array}{l}\text { DMH-, } \\
\text { DMBA-, } \\
\text { BBN-, } \\
\text { DHPN- } \\
\text { induced }\end{array}$ & $\begin{array}{l}\text { Oriental MF } \\
\text { basal diet }\end{array}$ & $\begin{array}{l}0.1 \% \text { or } 1 \% \text { CLA from } \\
\text { safflower oil }(71.3 \% \text { CLA })\end{array}$ & $\begin{array}{l}0.1 \% \text { CLA } \downarrow \text { mammary } \\
\text { cancer incidence more } \\
\text { than } 1 \% \text { CLA }\end{array}$ & $\begin{array}{l}1 \% \text { CLA } \uparrow \text { papillary or nodular } \\
\text { hyperplasia in bladder but not } \\
\text { tumours }\end{array}$ \\
\hline
\end{tabular}


Table 2. contd....

\begin{tabular}{|c|c|c|c|c|c|c|}
\hline Reference & Animal Model & Tumour & Basal Diet & CLA Content & Results & Mechanism Tested \\
\hline$[28]$ & $\begin{array}{l}\text { Female } \\
\text { Sprague- } \\
\text { Dawley rats }\end{array}$ & PhIP-induced & $\begin{array}{l}\text { Oriental MF } \\
\text { basal diet }\end{array}$ & $\begin{array}{l}0.1 \% \text { CLA-rich safflower } \\
\text { oil, fed during or after PhIP } \\
\text { treatment until termination }\end{array}$ & $\begin{array}{l}\text { CLA } \downarrow \text { mammary adeno- } \\
\text { carcinoma incidence when } \\
\text { fed in the post-initiation } \\
\text { period }\end{array}$ & $\begin{array}{l}\text { CLA } \downarrow \text { proliferation of mammary } \\
\text { adenocarcinoma cells when fed in } \\
\text { the post-initiation period } \\
\text { CLA } \downarrow \text { PhIP-DNA adduct formation } \\
\text { in mammary gland epithelial cells }\end{array}$ \\
\hline [29] & $\begin{array}{l}\text { Female } \\
\text { Sprague- } \\
\text { Dawley rats }\end{array}$ & NMU-induced & $\begin{array}{l}\text { AIN-76 basal } \\
\text { diet with } 5 \% \\
\text { w/w butter fat } \\
\text { in place of } \\
\text { corn oil }\end{array}$ & $\begin{array}{l}2 \% \text { VA or } 1 \% \mathrm{c} 9, \mathrm{t} 11 \mathrm{CLA}, \text { fed } \\
\text { from NMU-injection for } 6 \mathrm{wks}\end{array}$ & $\begin{array}{l}\text { VA and c9,t11 CLA } \\
\downarrow \text { premalignant lesions in } \\
\text { the mammary gland }\end{array}$ & $\begin{array}{l}\text { Dietary VA } \uparrow \text { CLA concentration in } \\
\text { mammary gland } \\
2 \% \text { VA } \downarrow \text { LA and LA metabolites in } \\
\text { the liver but not mammary gland }\end{array}$ \\
\hline$[37]$ & $\mathrm{Cd} 2 / \mathrm{F} 1$ mice & $\begin{array}{l}\text { EHS-RBM } \\
\text { in vivo } \\
\text { angiogenesis } \\
\text { model }\end{array}$ & $\begin{array}{l}\text { AIN-76A } \\
\text { with } 5 \% \text { corn } \\
\text { oil }\end{array}$ & $\begin{array}{l}0,1 \text { or } 2 \% \text { CLA }(50: 50 \text { mix } \\
\text { of c } 9, \mathrm{t} 11 \text { and } \mathrm{t} 10, \mathrm{c} 12), \\
\text { fed } 6 \text { wks prior to angiogenic } \\
\text { challenge }\end{array}$ & $\begin{array}{l}\text { Both CLA diets } \downarrow \text { forma- } \\
\text { tion of functional blood } \\
\text { vessels }\end{array}$ & $\begin{array}{l}\text { CLA } \downarrow \text { serum and mammary gland } \\
\text { levels of VEGF and its receptor, } \\
\text { Flk-1 }\end{array}$ \\
\hline$[30]$ & $\begin{array}{l}\text { Female } \\
\text { Sprague- } \\
\text { Dawley rats }\end{array}$ & NMU-induced & AIN-76 & $\begin{array}{l}0.5 \% \mathrm{c} 9, \mathrm{t} 11 \text { or } \mathrm{t} 10, \mathrm{c} 12 \text { CLA } \\
(90 \% \text { pure })\end{array}$ & $\begin{array}{l}\mathrm{c} 9, \mathrm{t} 11 \text { and } \mathrm{t} 10, \mathrm{c} 12 \mathrm{CLA} \\
\downarrow \text { premalignant intraductal } \\
\text { proliferations and } \\
\downarrow \text { tumour incidence }\end{array}$ & $\begin{array}{l}\text { c9,t11 CLA accumulated in } \\
\text { mammary fat pad to a greater extent } \\
\text { than t10,c12 CLA } \\
\text { t10,c12 CLA significantly } \downarrow 20: 2 \text {, } \\
20: 3,20: 4,22: 4,22: 6 \text { and } \uparrow 16: 1 \text {, } \\
16: 2 \text { in mammary fat pad, whereas } \\
\text { c9,t11 CLA had minimal effect } \\
\text { on polyunsaturated fatty acid } \\
\text { concentrations }\end{array}$ \\
\hline$[38]$ & $\begin{array}{l}\mathrm{BALB} / \mathrm{cAnN} \\
\text { mice }\end{array}$ & $\begin{array}{l}\text { Mouse } \\
\text { mammary } \\
\text { tumour cell } \\
\text { line } 4526\end{array}$ & $\begin{array}{l}20 \% \mathrm{w} / \mathrm{w} \\
\text { total fat }\end{array}$ & $\begin{array}{l}0,0.1, \text { or } 0.25 \% \mathrm{w} / \mathrm{w} \text { of } \mathrm{c} 9, \mathrm{t} 11 \\
\text { CLA, t10,c12 CLA, or } 0.125 \% \\
\mathrm{c} 9, \mathrm{t} 11 \mathrm{CLA}+0.125 \% \mathrm{t} 10, \mathrm{c} 12 \\
\text { CLA (CLA mix) }\end{array}$ & $\begin{array}{l}\text { Neither CLA isomer nor } \\
\text { the mix affected tumour } \\
\text { latency or growth } \\
\text { All CLA diets } \downarrow \text { tumour } \\
\text { burden in lungs and size of } \\
\text { pulmonary nodules }\end{array}$ & No mechanism tested \\
\hline [39] & $\begin{array}{l}\text { CD2FICr mice } \\
\mathrm{TNF} \alpha(+/+) \text { or } \\
(-/-)\end{array}$ & $\begin{array}{l}\text { Matrigel } \\
\text { pellet } \\
\text { angiogenesis } \\
\text { assay }\end{array}$ & AIN-76A & $\begin{array}{l}0,5, \text { or } 10 \mathrm{~g} / \mathrm{kg} \mathrm{c} 9, \mathrm{t} 11 \\
\text { or t10,c12 CLA (purified } \\
\text { isomers) }\end{array}$ & $\begin{array}{l}\text { Both isomers } \downarrow \text { serum } \\
\text { VEGF, formation of } \\
\text { functional blood vessels, } \\
\text { and } \downarrow \text { size of unilocular } \\
\text { adipocytes (effect was } \\
\text { greater with t10,c12 CLA } \\
\text { and reversible with c9,t11 } \\
\text { CLA) }\end{array}$ & $\begin{array}{l}\mathrm{t} 10, \mathrm{c} 12 \text { and CLA mix ablated BAT } \\
\mathrm{t} 10, \mathrm{c} 12 \mathrm{CLA} \downarrow \text { serum leptin and } \uparrow \\
\text { apoptosis of adipose blood vessels } \\
\text { and adipocytes } \\
\mathrm{c} 9, \mathrm{t} 11 \mathrm{CLA} \uparrow \mathrm{BAT} \text { in mammary } \\
\text { gland }\end{array}$ \\
\hline$[31]$ & $\begin{array}{l}\text { Sprague- } \\
\text { Dawley rats }\end{array}$ & $\begin{array}{l}\text { DMH- and } \\
\text { DMBA- } \\
\text { induced }\end{array}$ & $\begin{array}{l}\text { Oriental MF } \\
\text { diet }\end{array}$ & $\begin{array}{l}0.01,0.05,0.1,1 \text { or } 2 \% \\
\text { CLA-rich safflower oil, fed } \\
\text { following tumour initiation } \\
\text { until termination }\end{array}$ & $\begin{array}{l}1 \% \text { safflower oil } \\
\downarrow \text { adenocarcinoma } \\
\text { incidence }\end{array}$ & No mechanism tested \\
\hline$[32]$ & $\begin{array}{l}\text { Female } \\
\text { Sprague- } \\
\text { Dawley rats }\end{array}$ & NMU-induced & $\begin{array}{l}5 \% \mathrm{w} / \mathrm{w} \\
\text { sunflower oil }\end{array}$ & $\begin{array}{l}1 \% \mathrm{w} / \mathrm{w} \text { CLA mix or } 1 \% \mathrm{w} / \mathrm{w} \\
\mathrm{c} 9, \mathrm{t} 11 \mathrm{CLA}\end{array}$ & $\begin{array}{l}\text { Both CLA diets } \downarrow \text { tumour } \\
\text { mass, with no effect on } \\
\text { tumour incidence or latency }\end{array}$ & $\begin{array}{l}\text { CLA levels were higher in } \\
\text { mammary fat neutral lipids than } \\
\text { tumour PL }\end{array}$ \\
\hline$[33]$ & $\begin{array}{l}\text { Female } \\
\text { Sprague- } \\
\text { Dawley rats }\end{array}$ & NMU-induced & $\begin{array}{l}\text { AIN-76 with } \\
10 \% \mathrm{w} / \mathrm{w} \\
\text { butter fat }\end{array}$ & $\begin{array}{l}0.13,0.73,1.0, \text { or } 1.6 \% \mathrm{VA} \text {, or } \\
0.05,0.18,0.24 \text { or } 0.37 \mathrm{c} 9, \mathrm{t} 11 \\
\text { CLA, fed post-NMU injection } \\
\text { for } 24 \mathrm{wks}\end{array}$ & $\begin{array}{l}\text { VA } \downarrow \text { tumour number and } \\
\text { incidence to a greater } \\
\text { extent than c9,t11 CLA }\end{array}$ & $\begin{array}{l}\text { VA and c9,t11 CLA } \uparrow \text { amounts of } \\
\mathrm{c} 9, \mathrm{t} 11 \text { CLA in mammary fat pad }\end{array}$ \\
\hline$[40]$ & $\begin{array}{l}\text { Adult in-bred } \\
\text { ovary-intact, } \\
\text { non- } \\
\text { estrogenized } \\
\text { nude rats }\end{array}$ & $\begin{array}{l}\text { MCF-7 } \\
\text { xenografts }\end{array}$ & $\begin{array}{l}\text { Essential } \\
\text { FA-replete } \\
\text { diet }\end{array}$ & $\begin{array}{l}\text { Mammary tumours were } \\
\text { perfused in situ with donor } \\
\text { blood spiked with } 0-360 \mu \mathrm{M} \\
\mathrm{c} 9, \mathrm{t} 11, \mathrm{t} 9, \mathrm{t} 11 \text {, or } \mathrm{t} 10, \mathrm{c} 12 \mathrm{CLA}\end{array}$ & $\begin{array}{l}\mathrm{t} 10, \mathrm{c} 12 \text { CLA and } \mathrm{t} 9, \mathrm{t} 11 \\
\text { CLA, but not } \mathrm{c} 9, \mathrm{t} 11 \text { CLA, } \\
\downarrow \text { tumour }{ }^{3} \mathrm{H} \text {-thymidine } \\
\text { uptake }\end{array}$ & $\begin{array}{l}\text { t10,c12 CLA inhibited LA uptake, } \\
\text { cAMP content, ERK } 1 / 2 \text { activity, } \\
\text { and } 13 \text {-hydroxyoctadecadienoic } \\
\text { acid formation in mammary tu- } \\
\text { mours to a greater extent than } t 9, \mathrm{t} 11 \\
\text { CLA }\end{array}$ \\
\hline
\end{tabular}


Table 2. contd....

\begin{tabular}{|c|c|c|c|c|c|c|}
\hline Reference & Animal Model & Tumour & Basal Diet & CLA Content & Results & Mechanism Tested \\
\hline [34] & $\begin{array}{l}\text { Female } \\
\text { Sprague- } \\
\text { Dawley rats }\end{array}$ & NMU-induced & AIN-76 & $\begin{array}{l}0.13 \% \mathrm{w} / \mathrm{w} \text { VA or } 1.6 \% \mathrm{w} / \mathrm{w} \\
\mathrm{VA}+/- \text { sterculic oil, fed } \\
\text { post-NMU injection } \\
\text { for } 6 \mathrm{wks}\end{array}$ & $\begin{array}{l}1.6 \% \text { VA without sterculic } \\
\text { oil } \downarrow \text { the number of prema- } \\
\text { lignant lesions in the } \\
\text { mammary gland }\end{array}$ & $\begin{array}{l}1.6 \% \text { VA } \downarrow \text { the proliferative } \\
\text { activity of premalignant cells in the } \\
\text { mammary gland } \\
\text { Treatment with sterculic oil } \\
\text { reversed the effects of VA by } \\
\text { inhibiting } \Delta 9 \text {-desaturase activity, } \\
\text { suggesting that the anticarcinogenic } \\
\text { effects of VA are mediated through } \\
\text { conversion to c } 9, \mathrm{t} 11 \mathrm{CLA}\end{array}$ \\
\hline [41] & $\begin{array}{l}\text { Female } \\
\text { BALB/cAnN } \\
\text { mice }\end{array}$ & $\begin{array}{l}\text { Mouse } \\
\text { mammary } \\
\text { tumour cell } \\
\text { line } 4526\end{array}$ & $\begin{array}{l}20 \% \mathrm{w} / \mathrm{w} \text { fat } \\
\text { (vegetable fat } \\
\text { blend and/or } \\
\text { beef tallow or } \\
\text { corn oil) }\end{array}$ & $\begin{array}{l}0.05 \text { or } 0.1 \% \text { CLA mix }(33 \% \\
\mathrm{c} 9, \mathrm{t} 11 \text { and } 33 \% \mathrm{t} 10, \mathrm{c} 12)\end{array}$ & $\begin{array}{l}\text { CLA had no effect on } \\
\text { tumour growth rate }\end{array}$ & $\begin{array}{l}\text { CLA in vegetable fat blend/beef } \\
\text { tallow group } \downarrow \text { lung metastases } \\
\text { compared to other groups, } \\
\text { especially vegetable fat blend/corn } \\
\text { oil }\end{array}$ \\
\hline$[43]$ & $\begin{array}{l}\text { FVB/N-Tg } \\
\text { (MMTVneu) } \\
\text { 202Mul/J and } \\
\text { FVB/J female } \\
\text { mice }\end{array}$ & $\begin{array}{l}\text { ErbB2- } \\
\text { overexpress- } \\
\text { ing mammary } \\
\text { tumours }\end{array}$ & AIN-76A & $\begin{array}{l}0.5 \% \mathrm{c} 9, \mathrm{t} 11 \text { or } \mathrm{t} 10, \mathrm{c} 12 \mathrm{CLA} \\
(>90 \% \text { pure isomers), fed from } \\
\text { weaning or fed from } \sim 70 \mathrm{~d} \text { of } \\
\text { age }\end{array}$ & $\begin{array}{l}\text { t10,c12 CLA fed from } \\
\text { weaning or after puberty } \downarrow \\
\text { tumour latency and } \uparrow \text { lung } \\
\text { metastases, but had no } \\
\text { effect on the number or } \\
\text { size of primary tumours } \\
\text { c9,t11 CLA had no effect }\end{array}$ & $\begin{array}{l}\text { t10,c12 CLA slightly } \uparrow \text { survival } \\
\text { time compared to control } \\
\text { t10,c12 CLA } \downarrow \text { weight gain, } \\
\text { modified mammary gland } \\
\text { development, } \downarrow \text { adipocytes, } \uparrow \text { fibro- } \\
\text { cellular stroma, } \uparrow \text { size of } \\
\text { mammary lymph nodes, with no } \\
\text { change to ErbB2 expression or } \\
\text { localization } \\
\text { t10,c12 CLA } \uparrow \text { weight of spleen, } \\
\text { heart, and liver (fatty liver) } \\
\text { t10,c12 CLA } \uparrow \text { the number of } \\
\text { terminal end buds in the mammary } \\
\text { glands of wild-type mice }\end{array}$ \\
\hline [74] & $\begin{array}{l}\text { Female } \\
\text { BALB/cAnN } \\
\text { mice }\end{array}$ & $\begin{array}{l}\text { Mouse } \\
\text { mammary } \\
\text { tumour cell } \\
\text { line } 4526\end{array}$ & $\begin{array}{l}20 \% \mathrm{w} / \mathrm{w} \\
\text { total fat from } \\
\text { corn oil }\end{array}$ & $\begin{array}{l}0.1,0.5, \text { or } 1 \% \mathrm{w} / \mathrm{w} \text { CLA }(33 \% \\
\mathrm{c} 9, \mathrm{t} 11 \mathrm{CLA} \text { and } 34 \% \mathrm{t} 10, \mathrm{c} 12 \\
\text { CLA })\end{array}$ & $\begin{array}{l}\text { Effects of CLA on tumour } \\
\text { growth not reported }\end{array}$ & $\begin{array}{l}\text { CLA } \uparrow \text { mRNA levels of MMP-2 } \\
\text { and MMP-9 in tumour cells but } \\
\text { significantly } \downarrow \text { MMP-9 activity } \\
\text { levels } \\
\text { CLA } \uparrow \text { mRNA levels of tissue } \\
\text { inhibitors of metalloproteinases }\end{array}$ \\
\hline$[102]$ & $\begin{array}{l}\text { FVB/N-Tg } \\
\text { (MMTVneu) } \\
\text { 202Mul/J } \\
\text { ('ErbB2 } \\
\text { transgenic') } \\
\text { female mice }\end{array}$ & $\begin{array}{l}\text { ErbB2- } \\
\text { overexpress- } \\
\text { ing mammary } \\
\text { tumours }\end{array}$ & AIN-76A & $\begin{array}{l}0.5 \% \mathrm{c} 9, \mathrm{t} 11 \text { or } \mathrm{t} 10, \mathrm{c} 12 \mathrm{CLA} \\
(>90 \% \text { pure isomers), started at } \\
6-10 \mathrm{wks} \text { of age and fed for } 10 \\
\text { days, } 4 \mathrm{wks} \text {, or until death, } \\
\text { depending on the experiment }\end{array}$ & $\begin{array}{l}\text { t10,c12 CLA } \uparrow \text { mammary } \\
\text { tumour growth, } \uparrow \text { the } \\
\text { number of new tumours, } \downarrow \\
\text { latency, and } \downarrow \text { survival } \\
\text { t10,c12 CLA } \uparrow \text { mammary } \\
\text { gland branching, ductal } \\
\text { budding, and lobular } \\
\text { development } \\
\text { t10,c12 CLA } \uparrow \text { polymor- } \\
\text { phonuclear lymphocyte } \\
\text { infiltration and decreased } \\
\text { adipocytes in mammary } \\
\text { stroma } \\
\text { no effect of c9,t11 CLA }\end{array}$ & $\begin{array}{l}\text { t10,c12 CLA } \uparrow \text { phosphorylation } \\
\text { of PI3K, Akt, MEK, ERK and } \\
\text { IGF-IR/IR, with no effect on the } \\
\text { phosphorylation of ErbB2 } \\
\text { no effect of c9,t11 CLA }\end{array}$ \\
\hline
\end{tabular}

Abbreviations: AIN, American Institute of Nutrition; BBN, $N$-butyl- $N$-(4-hydroxybutyl)nitrosamine; cAMP, cyclic adenosine monophosphate; DHPN, dihydroxy-di- $n$ propylnitrosamine; DMBA, 7,12-dimethylbenz (a)anthracine; DMH, 1,2-dimethylhydrazine; EHS-RBM, Engelbreth-Holm-Swarm sarcoma-derived reconstituted basement membrane; ERK, extracellular signal-regulated kinase; FFA, free fatty acid; IGF-IR, insulin-like growth factor I receptor; IR, insulin receptor; MMP, matrix metalloproteinase; NMU, Nnitroso, N-methylurea; PhIP, 2-amino-1-methyl-6-phenylimidazo[4,5-b]pyridine; PI3K, phosphatidylinositol 3-kinase; PL, phospholipids; TG, triglyceride; VA, vaccenic acid; VEGF, vascular endothelial growth factor. 
Table 3. Cell Culture Studies of CLA and Breast Cancer

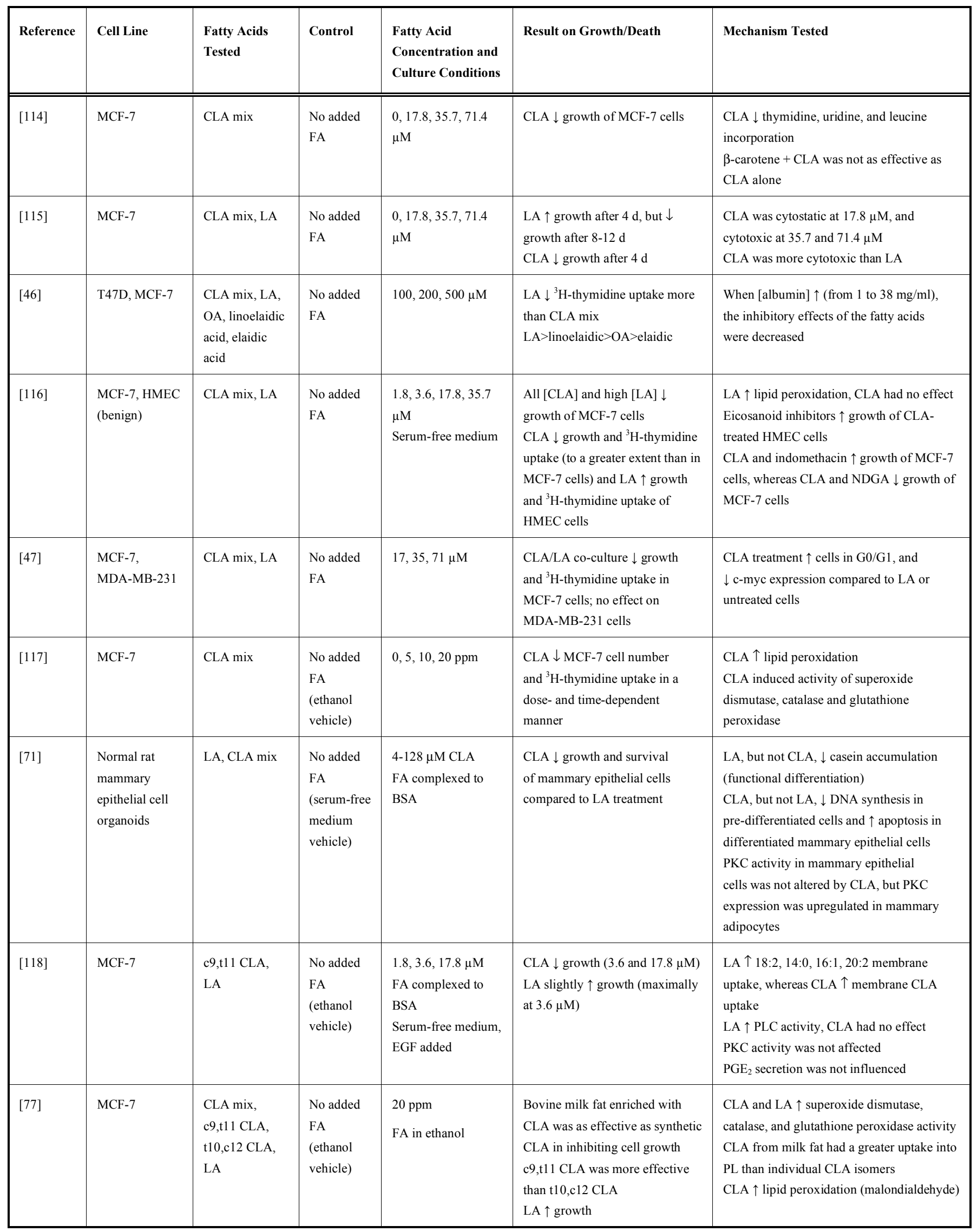


Table 3. contd....

\begin{tabular}{|c|c|c|c|c|c|c|}
\hline [94] & MCF-7 & $\begin{array}{l}\text { CLA mix }(29 \% \\
\text { t10,c12 and } \\
30 \% \text { c } 9, \mathrm{t} 11) \\
\text { c } 9, \mathrm{t} 11 \text { CLA, } \\
\text { t10,c12 CLA, } \\
\text { LA }\end{array}$ & $\begin{array}{l}\text { No added } \\
\text { FA } \\
\text { (ethanol } \\
\text { vehicle) }\end{array}$ & $\begin{array}{l}17.8-57 \mu \mathrm{M} \\
5 \% \mathrm{FBS}\end{array}$ & $\begin{array}{l}\text { CLA mix and c9,t11 CLA } \downarrow \\
\text { viability after } 4 d \\
\text { LA had no effect on MCF- } 7 \text { cells }\end{array}$ & $\begin{array}{l}\text { c9,t11 CLA, but not t10,c12 CLA, } \downarrow \text { AA } \\
\text { uptake into phosphatidylcholine and } \uparrow \text { AA } \\
\text { uptake into phosphatidylethanolamine } \\
\text { CLA mix and c9,t11 CLA } \downarrow \text { AA conversion } \\
\text { to } \text { PGE }_{2} \\
\text { c9,t11 CLA and t10,c12 CLA } \\
\uparrow \text { lipid peroxidation }\end{array}$ \\
\hline [119] & $\begin{array}{l}\text { MDA-MB-231, } \\
\text { MCF-7 }\end{array}$ & $\begin{array}{l}\text { CLA mix } \\
(48 \% \text { c9,t11 } \\
\text { and } 46 \% \\
\text { t10,c12), } \\
\text { c9,t11 CLA, } \\
\text { t10,c12 CLA, } \\
\text { LA }\end{array}$ & $\begin{array}{l}\text { No added } \\
\text { FA }\end{array}$ & $\begin{array}{l}45 \text { and } 100 \mu \mathrm{M} \\
\text { FA complexed to } \\
\text { BSA } \\
\text { Serum-free medium }\end{array}$ & $\begin{array}{l}\text { No measures of growth were } \\
\text { completed }\end{array}$ & $\begin{array}{l}\text { c9,t11 CLA and t10,c12 CLA } \\
\downarrow \text { stearoyl-CoA desaturase protein levels in } \\
\text { MDA-MB-231 but not MCF-7 cells } \\
\text { c9,t11 CLA and t10,c12 CLA } \\
\downarrow \text { stearoyl-CoA desaturase activity in both } \\
\text { cell lines } \\
\text { No effect on stearoyl CoA desaturase } \\
\text { mRNA levels in either cell line } \\
\text { LA } \downarrow \text { stearoyl-CoA desaturase mRNA and } \\
\text { protein levels in both cell lines } \\
\text { CLA } \downarrow \text { palmitoleic }(16: 1) \text { and oleic (18:1) } \\
\text { acid concentrations and } \downarrow \text { desaturation } \\
\text { indices in both cell lines }\end{array}$ \\
\hline [49] & $\begin{array}{l}\text { MCF-10A } \\
\text { (benign), } \\
\text { MCF-7, } \\
\text { MDA-MB-231 }\end{array}$ & $\begin{array}{l}\text { CLA mix } \\
(50: 50 \mathrm{c} 9, \mathrm{t} 11 \\
\text { and } \mathrm{t} 10, \mathrm{c} 12) \\
\mathrm{c} 9, \mathrm{t} 11 \text { CLA, } \\
\mathrm{t} 10, \mathrm{c} 12 \text { CLA, } \\
\text { LA }\end{array}$ & $\begin{array}{l}\text { No added } \\
\text { FA } \\
\text { (ethanol } \\
\text { vehicle) }\end{array}$ & $\begin{array}{l}0-200 \mu \mathrm{M} \\
\text { FA bound to BSA } \\
10 \% \text { FBS }\end{array}$ & $\begin{array}{l}\text { CLA mix } \downarrow \text { MCF- } 7 \text { and MDA- } \\
\text { MBA- } 231 \text { growth more than } \\
\text { individual isomers or LA } \\
\text { MCF-10A growth was inhibited } \\
\text { at lower doses }\end{array}$ & $\begin{array}{l}\text { CLA } \uparrow \text { expression of wild-type } \mathrm{p} 53 \text { mRNA } \\
\text { in MCF- } 7 \text { and MCF-10A cells, } \uparrow \text { expression } \\
\text { of p } 21 \mathrm{WAF} 1 / \mathrm{CIP} 1 \text { in MCF- } 7 \text { and } \\
\text { MDA-MB- } 231 \text { cells, and } \uparrow \text { expression of } \\
\text { bax and bcl- } 2 \text { in MDA-MB- } 231 \text { cells }\end{array}$ \\
\hline [120] & SKBR-3 & $\begin{array}{l}\text { c9,t11 CLA, } \\
\text { myristic acid }\end{array}$ & $\begin{array}{l}\text { No added } \\
\text { FA }\end{array}$ & $0.25 \mathrm{mM}$ & Not reported & $\begin{array}{l}\text { c9,t11 CLA } \downarrow \text { incorporation of }{ }^{14} \mathrm{C} \text {-acetate } \\
\text { into PL of SKBR-3 cells } \\
\text { c9,t11 CLA inhibited fatty acid synthase } \\
\text { activity, but not expression (mRNA), to a } \\
\text { greater extent than } 110, \mathrm{c} 12 \mathrm{CLA}\end{array}$ \\
\hline [48] & MCF-7 & $\begin{array}{l}\text { CLA mix, } \\
\text { c9,t11 CLA, } \\
\text { t10,c12 CLA }\end{array}$ & $\begin{array}{l}\text { No added } \\
\text { FA } \\
\text { (ethanol } \\
\text { vehicle or } \\
\text { medium } \\
\text { alone) }\end{array}$ & $\begin{array}{l}10,20,40,80,160 \\
\mu \mathrm{M} \\
10 \% \mathrm{FBS}\end{array}$ & $\begin{array}{l}40 \mu \mathrm{M} \text { CLA mix } \downarrow \text { cell viability } \\
\text { with trypan blue assay } \\
10 \mu \mathrm{M} \text { CLA mix } \downarrow \text { cell viability } \\
\text { as measured by MTT assay }\end{array}$ & $\begin{array}{l}160 \mu \mathrm{M} \text { CLA mix induced a cell cycle arrest } \\
\text { in G0/G1 } \\
160 \mu \mathrm{M} \text { CLA } \uparrow \mathrm{p} 53, \mathrm{p} 21, \mathrm{p} 27 \text { and hypo- } \\
\text { phosphorylated Rb proteins, and } \downarrow \text { cyclin D1 } \\
\text { and E protein levels } \\
\text { Effects of CLA on p } 21 \text { and cyclin E levels } \\
\text { were mediated by p } 53 \\
\text { t10,c12 CLA was more effective than c9,t11 } \\
\text { CLA at reducing cell viability and affecting } \\
\text { p53 and Rb levels }\end{array}$ \\
\hline [101] & MCF-7 & $\begin{array}{l}\text { CLA mix }(49 \% \\
\mathrm{c} 9, \mathrm{t} 11 \text { and } 41 \% \\
\mathrm{t} 10, \mathrm{c} 12)\end{array}$ & $\begin{array}{l}\text { No added } \\
\text { FA }\end{array}$ & $\begin{array}{l}10 \mu \mathrm{M} \\
1 \% \text { FBS or } \\
\text { charcoal-treated } \\
\text { FBS }\end{array}$ & $\begin{array}{l}\text { c9,t11 CLA was a more potent } \\
\text { inhibitor of proliferation of MCF- } \\
7 \text { cells grown in the absence of } \\
\text { growth factors than t10,c12 CLA } \\
\text { or CLA mix }\end{array}$ & $\begin{array}{l}\text { t10,c12 CLA was the strongest inhibitor of } \\
\text { estrogen-stimulated growth } \\
\text { t10,c12 CLA was the strongest inhibitor of } \\
\text { insulin-stimulated growth and cell viability } \\
\text { Neither isomer affected EGF-stimulated } \\
\text { growth }\end{array}$ \\
\hline
\end{tabular}


Table 3. contd....

\begin{tabular}{|c|c|c|c|c|c|c|}
\hline Reference & Cell Line & $\begin{array}{l}\text { Fatty Acids } \\
\text { Tested }\end{array}$ & Control & $\begin{array}{l}\text { Fatty Acid } \\
\text { Concentration and } \\
\text { Culture Conditions }\end{array}$ & Result on Growth/Death & Mechanism Tested \\
\hline [78] & MCF-7 & $\begin{array}{l}\text { Milk fat CLA, } \\
\text { c9,t11 CLA, } \\
\text { LA, OA, VA }\end{array}$ & $\begin{array}{l}\text { No added } \\
\text { FA } \\
\text { (ethanol } \\
\text { vehicle or } \\
\text { milk fat) }\end{array}$ & $\begin{array}{l}60.2,65.2,80.6 \mu \mathrm{M} \\
\text { CLA provided in } 1 \\
\mathrm{mg} / \mathrm{mL} \text { milk fat } \\
\text { samples } \\
5 \% \mathrm{FBS}\end{array}$ & $\begin{array}{l}\text { All } 3 \text { milk fat samples } \downarrow \text { cell } \\
\text { number in a dose-dependent } \\
\text { manner compared to untreated } \\
\text { cells } \\
\text { Milk fat CLA was more effective } \\
\text { at } \downarrow \text { cell number than c9,t11 CLA } \\
\text { provided at the same } \\
\text { concentrations } \\
\text { LA } \uparrow \text { cell number at } 44 \mu \mathrm{M} \text {, but } \downarrow \\
\text { cell number at } 156 \mu \mathrm{M} \\
\text { OA } \downarrow \text { cell number at } 952 \mu \mathrm{M} \\
\text { VA } \downarrow \text { cell number at } \\
111-164 \mu \mathrm{M}\end{array}$ & $\begin{array}{l}80.6 \mu \mathrm{M} \mathrm{CLA} \uparrow \mathrm{AA} \text { uptake into the } \\
\text { monoacylglycerol fraction } \\
80.6 \mu \mathrm{M} \text { CLA } \downarrow \text { AA conversion to } \\
\mathrm{PGE}_{2} \text { and } \uparrow \text { conversion to } \mathrm{PGF}_{2 \alpha} \text {, and } \uparrow \text { lipid } \\
\text { peroxidation (as measured by levels } \\
\text { of } 8 \text {-epi- } \mathrm{PGF}_{2 \alpha} \text { ) }\end{array}$ \\
\hline [69] & $\begin{array}{l}\text { MCF-7, MDA- } \\
\text { MB-231 }\end{array}$ & $\begin{array}{l}\text { CLA mix, } \\
\text { c9,t11 CLA, } \\
\text { t9,t11 CLA, } \\
\text { c9,c12 CLA, } \\
\text { t10,c12 CLA, } \\
\text { c11,t13 CLA }\end{array}$ & $\begin{array}{l}\text { No added } \\
\text { FA } \\
\text { (solvent } \\
\text { vehicle) }\end{array}$ & $\begin{array}{l}25-200 \mu \mathrm{M} \\
10 \% \text { FBS }\end{array}$ & $\begin{array}{l}\mathrm{c} 9, \mathrm{c} 11 \text { CLA inhibited MCF-7 } \\
\text { cell growth }>\mathrm{t} 10, \mathrm{c} 12>\mathrm{t} 9, \mathrm{t} 11> \\
\mathrm{c} 11, \mathrm{t} 13>\mathrm{c} 9, \mathrm{t} 11 \mathrm{CLA} \\
\text { CLA did not inhibit MDA-MB- } \\
231 \text { cell growth }\end{array}$ & $\begin{array}{l}\text { CLA } \downarrow \text { ER } \alpha \text { mRNA and protein levels } \\
\text { CLA } \downarrow \text { nuclear binding of ER } \alpha \text { to the } \\
\text { estrogen response element (ERE), as well as } \\
\text { inhibition of ERE promoter activity } \\
\text { CLA inhibition of ERE was not entirely } \\
\text { accounted for by } \downarrow \text { ER } \alpha \text { levels } \\
\text { CLA isomers differentially activated a } \\
\text { PPAR response element (c9,c11 > c9,t11), } \\
\text { suggesting that PPAR complexes might } \\
\text { compete with activated ER for binding to } \\
\text { the ERE }\end{array}$ \\
\hline$[67]$ & $\begin{array}{l}\text { MCF-7, MDA- } \\
\text { MB-231 }\end{array}$ & $\begin{array}{l}\text { CLA, } \\
\text { LA }\end{array}$ & $\begin{array}{l}\text { No added } \\
\text { FA } \\
\text { (serum-free } \\
\text { medium } \\
\text { vehicle) }\end{array}$ & $\begin{array}{l}100 \mu \mathrm{M} \\
5 \% \mathrm{FBS}\end{array}$ & $\begin{array}{l}\text { CLA } \downarrow \text { growth of both cell lines } \\
\text { At the same concentration, } \\
\text { CLA was less effective in } \\
\text { MDA-MB- } 231 \text { cells }\end{array}$ & $\begin{array}{l}\mathrm{CLA} \uparrow \operatorname{PPAR} \gamma \text { and } \downarrow \text { PPAR } \beta / \delta \text { protein } \\
\text { levels in MCF- } 7 \text { cells } \\
\mathrm{CLA} \uparrow \operatorname{PPAR} \beta / \delta, \uparrow \operatorname{PPAR} \gamma 2 \text {, and } \\
\text { had no affect on PPAR } \alpha \text { protein } \\
\text { levels in MDA-MB- } 231 \text { cells }\end{array}$ \\
\hline [93] & $\begin{array}{l}4526 \text { mouse } \\
\text { mammary } \\
\text { tumour cells }\end{array}$ & $\begin{array}{l}\mathrm{c} 9, \mathrm{t} 11 \text { CLA, } \\
\mathrm{t} 10, \mathrm{c} 12 \mathrm{CLA}, \\
\mathrm{LA}\end{array}$ & $\begin{array}{l}\text { No added } \\
\text { FA } \\
\text { (ethanol } \\
\text { vehicle) }\end{array}$ & $\begin{array}{l}10,50,100 \mu \mathrm{M} \\
5 \% \text { FBS in } \\
\text { serum-free medium } \\
\text { Insulin, transferrin, } \\
\text { BSA }\end{array}$ & $\begin{array}{l}\text { t10,c12 CLA } \downarrow \text { viability at } 10,50 \\
\text { and } 100 \mu \mathrm{M} \text { after } 48 \mathrm{hr} \\
\text { LA had no effect }\end{array}$ & $\begin{array}{l}\text { t10,c12 CLA } \uparrow \text { apoptosis and } \downarrow \text { cell prolife- } \\
\text { ration } \\
\text { t10,c12 CLA } \downarrow 5 \text {-HETE production } \\
\text { Adding 5-HETE into media } \downarrow \text { the effects of } \\
\text { t10,c12 CLA on apoptosis and proliferation }\end{array}$ \\
\hline$[50]$ & $\begin{array}{l}\text { MCF-7, } \\
\text { MCF-10A } \\
\text { (benign) }\end{array}$ & CLA mix & $\begin{array}{l}\text { No added } \\
\text { FA } \\
\text { (DMSO or } \\
\text { hydrogen } \\
\text { peroxide } \\
\text { vehicle) }\end{array}$ & $\begin{array}{l}0-50 \mu \mathrm{M} \\
10 \% \mathrm{FBS} \\
\text { Insulin }\end{array}$ & $\begin{array}{l}\text { CLA } \downarrow \text { growth of MCF- } 7 \text { cells } \\
\text { but not MCF-10A cells }\end{array}$ & $\begin{array}{l}\text { CLA } \uparrow \text { lipid peroxidation in MCF-7 cells } \\
\text { CLA } \uparrow \text { nuclear translocation of phosphory- } \\
\text { lated p53 and } \downarrow \text { phosphorylation of tran- } \\
\text { scription factor FKHRser } 256 \text { in MCF-7 cells } \\
\text { CLA } \downarrow \text { phosphorylated histone H3, blocking } \\
\text { entry into mitosis in MCF-7 cells }\end{array}$ \\
\hline$[121]$ & MCF-7 & $\begin{array}{l}\text { CLA mix }(50 \% \\
\mathrm{c} 9, \mathrm{t} 11,40 \% \\
\mathrm{t} 10, \mathrm{c} 12, \text { and } \\
10 \% \mathrm{c} 10, \mathrm{c} 12)\end{array}$ & $\begin{array}{l}\text { No added } \\
\text { FA } \\
\text { (solvent } \\
\text { vehicle) }\end{array}$ & $\begin{array}{l}25-200 \mu \mathrm{M} \\
10 \% \mathrm{FBS}\end{array}$ & Not reported & $\begin{array}{l}\text { CLA } \downarrow \text { progesterone receptor mRNA levels, } \\
\text { ER } \alpha \text { protein levels, ER } \alpha \text { phosphorylation, } \\
\text { and ER } \alpha \text {-ERE binding } \\
\text { CLA } \uparrow \text { protein phosphatase } 2 A \text { activity } \\
\text { (which dephosphorylates ER } \alpha \text { and thus } \\
\text { inhibits its transactivating potential) }\end{array}$ \\
\hline$[45]$ & $\begin{array}{l}\text { MCF-7 cells } \\
\text { co-cultured } \\
\text { with human } \\
\text { breast stromal } \\
\text { cells }\end{array}$ & $\begin{array}{l}\text { c9,t11 CLA, } \\
\text { t10,c12 CLA }\end{array}$ & $\begin{array}{l}\text { No added } \\
\text { FA }\end{array}$ & $\begin{array}{l}40 \mu \mathrm{M} \\
5 \% \mathrm{FBS} \text { in } \\
\text { dextran-charcoal- } \\
\text { treated medium }\end{array}$ & $\begin{array}{l}\text { Both isomers } \downarrow \text { proliferation of } \\
\text { MCF- } 7 \text { cells } \\
\text { t10,c12 CLA was more effective } \\
\text { when MCF-7 cells were } \\
\text { co-cultured with stromal cells }\end{array}$ & $\begin{array}{l}\text { t10,c12 CLA } \downarrow \text { VEGF-A mRNA and protein } \\
\text { levels to a greater extent than } \mathrm{c} 9, \mathrm{t} 11 \mathrm{CLA}\end{array}$ \\
\hline
\end{tabular}


Table 3. contd....

\begin{tabular}{|c|c|c|c|c|c|c|}
\hline Reference & Cell Line & $\begin{array}{l}\text { Fatty Acids } \\
\text { Tested }\end{array}$ & Control & $\begin{array}{l}\text { Fatty Acid } \\
\text { Concentration and } \\
\text { Culture Conditions }\end{array}$ & Result on Growth/Death & Mechanism Tested \\
\hline$[122]$ & $\begin{array}{l}\text { Primary breast } \\
\text { epithelial cells } \\
\text { and stromal } \\
\text { cells, MCF-7, } \\
\text { MDA-MB-231 }\end{array}$ & $\begin{array}{l}\text { c9,t11 CLA, } \\
\text { t10,c12 CLA }\end{array}$ & $\begin{array}{l}\text { No added } \\
\text { FA }\end{array}$ & $\begin{array}{l}40 \mu \mathrm{M} \\
5 \% \mathrm{FBS} \text { in phenol } \\
\text { red-free, high- } \\
\text { calcium, charcoal- } \\
\text { treated DMEM/F12 } \\
\text { medium }\end{array}$ & Not reported & $\begin{array}{l}\text { Both CLA isomers } \uparrow \text { expression of the } \\
\text { estrogen-regulated tumour suppressor gene, } \\
\text { protein tyrosine phosphatase gamma, in } \\
\text { primary cultured normal breast epithelial } \\
\text { cells, normal breast stromal cells and breast } \\
\text { cancer epithelial cells, but not in breast } \\
\text { cancer stromal cells } \\
\text { t10,c12 CLA appeared more effective than } \\
\text { c9,t11 CLA, especially in ER } \alpha \text {-positive } \\
\text { breast cancer epithelial cells }\end{array}$ \\
\hline [123] & $\begin{array}{l}\text { MCF-7, MDA- } \\
\text { MB-231 }\end{array}$ & $\begin{array}{l}\text { CLA mix, } \\
\text { c9,t11 CLA, } \\
\text { t10,c12 CLA }\end{array}$ & $\begin{array}{l}\text { No added } \\
\text { FA }\end{array}$ & $\begin{array}{l}20,40,80 \mu \mathrm{M} \\
0.5 \% \mathrm{FBS} \text { in } \\
\text { DMEM }\end{array}$ & Not reported & $\begin{array}{l}\text { CLA } \downarrow \text { COX- } 2 \text { transcription by } \\
\text { interfering with the recruitment of } \\
\text { activator protein-1 }\end{array}$ \\
\hline [124] & MCF-7 & $\begin{array}{l}\text { FA extracts } \\
\text { prepared from } \\
\text { beef lipid and } \\
\text { varying in CLA } \\
\text { content, } \\
\text { purified CLA- } \\
\text { enriched } \\
\text { fractions, and } \\
\text { mixtures of } \\
\text { pure synthetic } \\
\text { CLA isomers }\end{array}$ & $\begin{array}{l}\text { No added } \\
\text { FA } \\
\text { (ethanol } \\
\text { vehicle) }\end{array}$ & $100 \mu \mathrm{M}$ & $\begin{array}{l}\text { Beef total FA } \downarrow \text { cancer cell } \\
\text { growth to a greater extent than } \\
\text { the corresponding CLA-enriched } \\
\text { fractions } \\
\text { The greatest } \downarrow \text { in cell growth was } \\
\text { seen in mixtures with cis-trans } \\
\text { isomers (vs. cis-cis or trans-trans } \\
\text { isomers) }\end{array}$ & Not studied \\
\hline [126] & MDA-MB-231 & $\begin{array}{l}\text { CLA (not } \\
\text { defined) }\end{array}$ & $\begin{array}{l}\text { No added } \\
\text { FA } \\
\text { (serum-free } \\
\text { medium } \\
\text { vehicle) }\end{array}$ & $\begin{array}{l}60 \mu \mathrm{M} \\
10 \% \mathrm{FBS} \text { in } \\
\text { serum-free DMEM } \\
\text { Insulin, transferrin, } \\
\text { selenite, glutamine, } \\
\text { antibiotic, albumin }\end{array}$ & $\begin{array}{l}\text { CLA } \downarrow \text { cell growth and viability } \\
\text { after prolonged exposure } \\
(48-72 \mathrm{~h}) \\
\text { CLA } \uparrow \text { the } \% \text { of apoptotic cells at } \\
48 \text { and } 72 \mathrm{~h}\end{array}$ & $\begin{array}{l}\text { CLA } \uparrow \text { the accumulation of cells in S phase } \\
\text { and } \uparrow \text { markers of apoptosis (condensed } \\
\text { chromatin, } \uparrow \text { bak protein levels, } \downarrow \mathrm{Bcl}_{\mathrm{XL}} \\
\text { protein levels, } \uparrow \text { translocation of cytochrome } \\
\text { c to the nucleus, } \uparrow \text { pro-caspase } 3 \text { and } 9 \\
\text { cleavage) } \\
\text { CLA } \downarrow \text { Raf- } 1 \text { and phosphorylated ERK } 1 / 2 \\
\text { protein levels }\end{array}$ \\
\hline [125] & MCF-7 & $\begin{array}{l}\text { CLA mix } \\
(50: 50 \mathrm{c} 9, \mathrm{t} 11 \\
\text { and } \mathrm{t} 10, \mathrm{c} 12)\end{array}$ & $\begin{array}{l}\text { No added } \\
\text { FA }\end{array}$ & $\begin{array}{l}5,10,20,40,60, \\
100 \mu \mathrm{M} \\
10 \% \mathrm{FBS} \text { in } \\
\text { serum-free DMEM } \\
\text { Insulin, transferrin, } \\
\text { selenite, glutamine, } \\
\text { antibiotic, albumin }\end{array}$ & $\begin{array}{l}\text { CLA } \downarrow \text { cell growth time- and } \\
\text { dose-dependently, which was } \\
\text { maximal with } 60 \mu \mathrm{M} \text { and at } 72 \mathrm{~h} \\
\text { CLA } \uparrow \text { lactate dehydrogenase } \\
\text { release at } 72 \mathrm{~h}\end{array}$ & $\begin{array}{l}\text { CLA } \downarrow \text { Raf- } 1 \text { protein levels, phosphorylated } \\
\text { ERK } 1 / 2 \text { levels, and c-myc protein levels } \\
\text { CLA } \uparrow \text { protein phosphatase } 2 \text { A protein } \\
\text { levels } \\
\text { CLA did not affect levels of proteins } \\
\text { involved in apoptosis signaling (bak, Bcl }{ }_{\mathrm{XL}} \text {, } \\
\text { caspases) }\end{array}$ \\
\hline$[68]$ & MCF-7 & CLA mix & $\begin{array}{l}\text { No added } \\
\text { FA }\end{array}$ & $\begin{array}{l}60 \mu \mathrm{M} \\
10 \% \mathrm{FBS} \text { in } \\
\text { serum-free DMEM } \\
\text { Insulin, transferrin, } \\
\text { selenite, glutamine, } \\
\text { antibiotic, albumin }\end{array}$ & $\begin{array}{l}\text { CLA effects on tumour cell } \\
\text { growth have been reported in [67] } \\
\text { and [125] }\end{array}$ & $\begin{array}{l}\mathrm{CLA} \uparrow \operatorname{PPAR} \gamma \text { protein levels and caused } \\
\operatorname{PPAR} \gamma \text { translocation to nucleus } \\
\mathrm{CLA} \uparrow \text { protein levels of } \beta \text {-catenin and } \\
\text { E-cadherin and } \uparrow \text { membrane association of } \\
\beta \text {-catenin }\end{array}$ \\
\hline$[127]$ & MCF-7 & $\begin{array}{l}\text { CLA mix (CLA } \\
\text { conjugated to } \\
\text { polymeric } \\
\text { carrier) }\end{array}$ & $\begin{array}{l}\text { No added } \\
\text { FA }\end{array}$ & $50,100,200 \mu \mathrm{M}$ & $\begin{array}{l}\text { Plu-conjugated CLA } \downarrow \text { cell } \\
\text { viability more than unconjugated } \\
\text { CLA }\end{array}$ & Plu-CLA $\uparrow \mathrm{p} 53, \downarrow$ bcl- $2, \uparrow$ bax \\
\hline
\end{tabular}


Table 3. contd....

\begin{tabular}{|c|c|c|c|c|c|c|}
\hline Reference & Cell Line & $\begin{array}{l}\text { Fatty Acids } \\
\text { Tested }\end{array}$ & Control & $\begin{array}{l}\text { Fatty Acid } \\
\text { Concentration and } \\
\text { Culture Conditions }\end{array}$ & Result on Growth/Death & Mechanism Tested \\
\hline$[95]$ & MCF-7 & $\begin{array}{l}\mathrm{c} 9, \mathrm{t} 11 \text { CLA, } \\
\mathrm{t} 10, \mathrm{c} 12 \text { CLA, } \\
\text { CLA mix }(50 \% \\
\mathrm{c} 9, \mathrm{t} 11 \text { and } \\
\mathrm{t} 9, \mathrm{c} 11,40 \% \\
\mathrm{t} 10, \mathrm{c} 12,10 \% \\
\mathrm{c} 10, \mathrm{c} 12)\end{array}$ & $\begin{array}{l}\text { No added } \\
\text { FA }\end{array}$ & $20,40,80,160 \mu \mathrm{M}$ & Not reported & $\begin{array}{l}\text { Transcription activity of the COX- } 2 \\
\text { promoter was equally repressed by the CLA } \\
\text { mix and t10,c } 12 \text { CLA at all concentrations; } \\
\text { c9,t11 CLA was less effective } \\
\text { t10,c12 CLA } \downarrow \text { COX-2 protein expression to } \\
\text { a greater extent than c9,t11 CLA }\end{array}$ \\
\hline$[128]$ & $\begin{array}{l}\text { MCF-7, MDA- } \\
\text { MB-231 }\end{array}$ & $\begin{array}{l}\mathrm{c} 9, \mathrm{t} 11 \text { CLA, } \\
\mathrm{t} 10, \mathrm{c} 12 \text { CLA, } \\
\text { CLA mix } \\
(50: 50 \mathrm{c} 9, \mathrm{t} 11 \\
\text { and } \mathrm{t} 10, \mathrm{c} 12)\end{array}$ & $\begin{array}{l}\text { No added } \\
\text { FA, LA }\end{array}$ & $40 \mu \mathrm{M}$ & $\begin{array}{l}\text { t10,c12 CLA and CLA mix } \downarrow \\
\text { MDA-MB-231 cell viability } \\
\text { compared to no added FA after } \\
48 \text { and } 72 \mathrm{~h} \\
\text { t10,c12 CLA } \downarrow \text { MCF-7 cell } \\
\text { viability only after } 72 \mathrm{~h} \\
\text { c9,t11 CLA and LA had no } \\
\text { effects on viability of either cell } \\
\text { line }\end{array}$ & Not studied \\
\hline [74] & $\begin{array}{l}4526 \text { mouse } \\
\text { mammary } \\
\text { tumour cells }\end{array}$ & $\begin{array}{l}\text { CLA (not } \\
\text { defined) }\end{array}$ & $\begin{array}{l}\text { No added } \\
\text { FA, LA, } \\
\text { AA, OA }\end{array}$ & $10,100,1000 \mathrm{nM}$ & Not reported & $\begin{array}{l}\text { CLA at all concentrations } \downarrow \text { the number of } \\
\text { invasive cells (migration of tumour cells } \\
\text { through an extracellular matrix) compared to } \\
\text { no added FA, LA, AA and OA }\end{array}$ \\
\hline$[57]$ & $\begin{array}{l}\text { p53-mutant } \\
\text { TM4t mouse } \\
\text { mammary } \\
\text { tumour cells }\end{array}$ & $\mathrm{t} 10, \mathrm{c} 12 \mathrm{CLA}$ & $\begin{array}{l}\text { No added } \\
\text { FA }\end{array}$ & $10-40 \mu \mathrm{M}$ & $\begin{array}{l}\text { t10,c12 CLA } \downarrow \text { cell viability in a } \\
\text { concentration-dependent manner } \\
\text { compared to the control }\end{array}$ & $\begin{array}{l}\text { t10,c12 CLA induced apoptosis as indicated } \\
\text { by cell morphology (cell shrinkage and } \\
\text { membrane blebbing), cleavage of caspases } 3 \\
\text { and } 9 \text {, release of cytochrome c into the } \\
\text { cytosol, and } \downarrow \text { bcl-2 protein levels } \\
\text { No effect of CLA on bak or bax protein } \\
\text { levels }\end{array}$ \\
\hline$[51]$ & MCF-7 & $\begin{array}{l}\text { Polyethylene } \\
\text { glycol- } \\
\text { conjugated } \\
\text { CLA mix } \\
\text { (PCLA) }\end{array}$ & $\begin{array}{l}\text { CLA mix } \\
(46 \% \\
\mathrm{c} 9, \mathrm{t} 11 \text { and } \\
50 \% \\
\mathrm{t} 10, \mathrm{c} 12)\end{array}$ & $50-200 \mu \mathrm{M}$ & $\begin{array}{l}\text { PCLA and CLA reduced cell } \\
\text { viability equally at } 50,100 \text { and } \\
200 \mu \mathrm{M}\end{array}$ & $\begin{array}{l}\text { PCLA and CLA delayed cell entry into S } \\
\text { phase of the cell cycle and } \uparrow \text { the number of } \\
\text { cells in sub G1 phase } \\
\text { PCLA and CLA } \uparrow \text { p53 and bax protein } \\
\text { levels and } \downarrow \text { bcl- } 2 \text { protein levels }\end{array}$ \\
\hline$[54]$ & MCF-7 & $\begin{array}{l}\mathrm{t}, \mathrm{t} \text { CLA }(44 \% \\
\mathrm{t} 9, \mathrm{t} 11 \mathrm{CLA}, \\
42 \% \mathrm{t} 10, \mathrm{t} 12 \\
\text { CLA }) \\
\mathrm{c} 9, \mathrm{t} 11 \text { CLA, } \\
\mathrm{t} 10, \mathrm{c} 12 \text { CLA }\end{array}$ & LA & $5-60 \mu \mathrm{M}$ & $\begin{array}{l}40 \mu \mathrm{M} \text { t,t CLA inhibited cell } \\
\text { growth to a greater extent than } 40 \\
\mu \mathrm{M} \mathrm{c} 9, \mathrm{t} 11 \text { or } \mathrm{t} 10, \mathrm{c} 12 \mathrm{CLA}\end{array}$ & $\begin{array}{l}\text { t,t CLA } \uparrow \mathrm{p} 53 \text { and bax protein levels, } \\
\downarrow \text { bcl-2 protein levels, } \uparrow \text { cytochrome c re- } \\
\text { lease from the mitochondria, } \\
\uparrow \text { caspase- } 3 \text { activation and PARP cleavage } \\
\text { compared to c9,t11 CLA, t10,c12 } \\
\text { CLA and LA }\end{array}$ \\
\hline [53] & $\begin{array}{l}\text { p53-mutant } \\
\text { TM4t mouse } \\
\text { mammary } \\
\text { tumour cells }\end{array}$ & $\begin{array}{l}\text { c9,t11 CLA, } \\
\text { t10,c12 CLA }\end{array}$ & $\begin{array}{l}\text { No added } \\
\text { FA }\end{array}$ & $10-40 \mu \mathrm{M}$ & $\begin{array}{l}\text { t10,c12 CLA } \downarrow \text { cell viability in a } \\
\text { concentration-dependent manner } \\
\text { compared to the control }\end{array}$ & $\begin{array}{l}\mathrm{t} 10, \mathrm{c} 12 \mathrm{CLA} \text { induced apoptosis via } \\
\text { endoplasmic reticulum stress, as indicated } \\
\text { by dilatation of the endoplasmic reticulum, } \uparrow \\
\text { expression and splicing of X-box binding } \\
\text { protein- } 1 \text { mRNA, } \uparrow \text { phosphorylation of } \\
\text { eukaryotic initiation factor } 2 \alpha, \uparrow \text { expression } \\
\text { of the CHOP/GADD153 proapoptotic } \\
\text { transcription factor, PARP cleavage, and } \uparrow \\
\text { caspase- } 12 \text { cleavage }\end{array}$ \\
\hline$[56]$ & $\begin{array}{l}\mathrm{ER} \alpha(+) \\
\text { transfected and } \\
\text { wild type } \\
\text { MDA-MB-231 } \\
\text { cells }\end{array}$ & $\begin{array}{l}\text { Not stated, } \\
\text { assumed } \\
\text { mixture of } \\
\text { c9,t11 CLA, } \\
\text { t10,c12 CLA }\end{array}$ & $\begin{array}{l}\text { No added } \\
\text { FA }\end{array}$ & 10 and $80 \mu \mathrm{M}$ & $\begin{array}{l}\text { CLA } \uparrow \text { apoptosis in } \operatorname{ER} \alpha(+) \\
\text { transfected MDA-MB- } 231 \text { cells } \\
\text { but not in the wild type MDA- } \\
\text { MB-231 cells }\end{array}$ & $\begin{array}{l}\text { CLA } \downarrow \text { estrogen-stimulated bcl- } 2 \text { protein } \\
\text { expression in } \mathrm{ER} \alpha(+) \text { breast cells }\end{array}$ \\
\hline
\end{tabular}


Table 3. contd....

\begin{tabular}{|c|c|c|c|c|c|c|}
\hline Reference & Cell Line & $\begin{array}{l}\text { Fatty Acids } \\
\text { Tested }\end{array}$ & Control & $\begin{array}{l}\text { Fatty Acid } \\
\text { Concentration and } \\
\text { Culture Conditions }\end{array}$ & Result on Growth/Death & Mechanism Tested \\
\hline$[55]$ & SKBr3 & $\mathrm{t} 10, \mathrm{c} 12 \mathrm{CLA}$ & $\begin{array}{l}\text { No added } \\
\text { FA }\end{array}$ & $40,80 \mu \mathrm{M}$ & $\begin{array}{l}\text { t10,c12 CLA } \uparrow \mathrm{TNF} \alpha \text {-induced } \\
\text { apoptosis }\end{array}$ & $\begin{array}{l}\text { CLA } \downarrow \text { HER2 protein expression, nuclear } \\
\text { protein levels of NF- } \mathrm{b} b \text {, and } \downarrow \mathrm{PGE}_{2} \text { produc- } \\
\text { tion when AA was provided, suggesting } \\
\text { lower COX-2 activity }\end{array}$ \\
\hline [88] & MCF-7 & $\begin{array}{l}\text { c9,t11 CLA, } \\
\text { t10,c12 CLA }\end{array}$ & $\begin{array}{l}\text { No added } \\
\text { FA, LA, } \\
\text { OA }\end{array}$ & $\begin{array}{l}128 \mu \mathrm{M} \text { CLA } \\
\text { co-cultured with } \mu \mathrm{M} \\
\text { LA }\end{array}$ & $\begin{array}{l}\text { Both CLA isomers } \downarrow \text { cell growth } \\
\text { at } 48 \mathrm{~h}(\mathrm{t} 10, \mathrm{c} 12>\mathrm{c} 9, \mathrm{t} 11) \\
\text { compared to LA-treated cells } \\
\mathrm{t} 10, \mathrm{c} 12 \mathrm{CLA} \uparrow \text { lactate dehydro- } \\
\text { genase release at } 48 \mathrm{~h}\end{array}$ & $\begin{array}{l}\text { t10,c12 CLA } \downarrow \text { total and phosphorylated } \\
\text { IGF-IR protein levels } \\
\text { Both isomers } \downarrow \text { insulin receptor } \\
\text { substrate- } 1 \text { protein levels compared to } \\
\text { untreated cells }\end{array}$ \\
\hline [96] & $\begin{array}{l}\text { MDA-MB-231, } \\
\text { T47D }\end{array}$ & $\begin{array}{l}\text { c9,t11 CLA, } \\
\text { t10,c12 CLA, } \\
\text { mixture of } \\
\text { isomers }\end{array}$ & $\begin{array}{l}\text { LA and } \\
\text { palmitic } \\
\text { acid }\end{array}$ & $8-64 \mu \mathrm{M}$ & $\begin{array}{l}\text { Both isomers alone and in com- } \\
\text { bination caused a dose-related } \downarrow \\
\text { growth of both cell lines }\end{array}$ & $\begin{array}{l}\text { CLA mixture } \downarrow \text { S } 14 \text { and FAS mRNA } \\
\text { levels (involved in fatty acid synthesis) } \\
\text { in T47D cells }\end{array}$ \\
\hline
\end{tabular}

Abbreviations: AA, arachidonic acid; BSA, bovine serum albumin; COX, cyclooxygenase; DMSO, dimethyl sulfoxide; EGF, epidermal growth factor; ER, estrogen receptor; ERE, estrogen response element; ERK, extracellular signal-regulated kinase; FA, fatty acids; FBS, fetal bovine serum; 5-HETE, 5-hydroxyeicosatetraenoic acid; HMEC, human mammary epithelial cells; IGF-IR, insulin-like growth factor I receptor; LA, linoleic acid; MTT, methylthiazolyldiphenyl-tetrazolium bromide; NDGA, nordihydroguaiaretic acid; OA, oleic acid; $\mathrm{PGE}_{2}$, prostaglandin $\mathrm{E} 2 ; \mathrm{PGF}_{2 \alpha}$, prostaglandin $\mathrm{F} 2 \alpha$; PKC, protein kinase C; PL, phospholipids; PLC, phospholipase C; PPAR, peroxisome proliferator activated receptor; ppm, parts per million; VA, vaccenic acid.

and apoptosis. They consist of three isoforms (PPAR $\alpha$, $\mathrm{PPAR} \beta / \delta$ and PPAR $\gamma$ ) that are distributed in various tissues of the body and appear to have different yet also overlapping roles [58]. PPARs regulate gene expression by forming a heterodimer with retinoid $\mathrm{x}$ receptors, then binding to specific response elements in the promoter regions of target genes. PPAR $\gamma$ appears to be highly involved in adipocyte regulation, but it also appears as though its agonists target multiple hallmarks of cancer, including cell cycle arrest, differentiation, apoptosis, and angiogenesis [58]. PPAR $\gamma$ is expressed in human breast adenocarcinomas [59] and its upregulation decreases the proliferation of MCF-7 cells [60]. The role of PPAR $\beta / \delta$ ligands in tumourigenesis continues to be debated in the research literature [61]; there is evidence to support that they stimulate the growth of breast cancer cell lines [62]. There is limited data on the role of PPAR $\alpha$ agonists in cancer, however a PPAR $\alpha$ ligand has been shown to induce apoptosis in human breast cancer cell lines [63].

PUFAs and their metabolites are ligands for PPARs [6466]. CLA treatment of MCF-7 breast cancer cells was shown to increase protein levels of the anti-proliferative PPAR $\gamma$ and decrease protein levels of the anti-apoptotic PPAR $\beta / \delta$ $[67,68]$. CLA also increased the localization of PPAR $\gamma$ from the cytosol to the nucleus, and increased PPAR response element activation [68,69]. Use of a PPAR $\gamma$ antagonist abolished the growth inhibitory effects of CLA [68]. CLA exerted different effects on the estrogen receptor-negative MDA-MB-231 cell line [67]. It increased protein levels of the PPAR $\gamma 2$ isoform, yet it also increased PPAR $\beta / \delta$ levels, which may explain why CLA did not induce apoptosis in the MDA-MB-231 cells. Of note, none of these studies compared the effect of CLA on PPARs to that of other known PPAR agonists, such as linoleic, oleic or linolenic acids.

\section{Effects on the Tumour Microenvironment}

The tumour microenvironment plays an active role in tumourigenesis. The tissue that surrounds and intercalates between cancer cells is termed the tumour stroma and it consists of the extracellular matrix (ECM), immune and inflammatory cells, fibroblasts, adipocytes, and endothelial cells. Cross-talk between cancer and stromal cells is important for the creation of a microenvironment supportive of malignant tumour growth as well as for the promotion and progression of the tumour [70]. Cancer cells release growth factors such as basic fibroblast growth factor and the family of vascular endothelial growth factors (VEGF) to stimulate changes in the stroma to support the tumour's development. Proteases are also released, which remodel the surrounding ECM to allow the spreading of the cancer cells. Once activated, stromal fibroblasts produce more growth factors to stimulate the continued growth of the cancer cells [70]. The formation of blood vessels (angiogenesis) is critical to support tumour growth and progression. Cross talk between cancer cells that release VEGF and stromal endothelial cells that express the VEGF2 receptor results in local angiogenesis. Blocking VEGF2 has been shown to reverse invasive carcinoma to a pre-malignant non-invasive tumour phenotype [70].

Including CLA (up to $1 \% \mathrm{w} / \mathrm{w}$ ) in the diet has been shown to alter mammary gland development during puberty in rodents [24]. CLA decreased epithelial branching and the density of terminal end buds, which are highly susceptible to carcinogenesis $[24,71]$. The epithelial branching and terminal end bud formation of mammary gland development are dependent on the presence of stromal fibroblasts [72], which suggests CLA may interfere with signaling between the stroma and epithelial cells. There is evidence to support that the decreased epithelial branching could be due to CLA's 
direct inhibition of epithelial growth; however, changes in adipocyte stroma due to incubation with CLA have been observed and could also contribute $[25,71]$.

Both c9,t11 CLA and t10,c12 CLA have been shown to decrease the formation of microcapillary networks in mice and in vitro, although t10,c12 was more potent [37, 39]. Changes to pathways related to angiogenesis included: decreased VEGF-A serum levels, decreased local production of VEGF in the mammary gland, decreased VEGF2 receptor protein, and decreased serum leptin (which promotes angiogenesis through endothelial cells) $[37,39,45]$. Studying the effect of CLA on the stroma in the mouse model has been hampered by t10,c12 CLA's complete ablation of brown adipose tissue in the mammary gland, which thereby would change the composition of the surrounding stroma. However, in other tissues, the ability of CLA to reduce angiogenesis is well characterized [73]. Recent studies also report a reduction in the activity of matrix metalloproteinases in both mammary tumours [74] and colon cancer cells [75] with CLA treatment, suggesting an additional mechanism by which CLA may reduce tumour invasion and spread.

\section{Lipid Oxidation}

Tumour cells demonstrate an increased susceptibility to oxidative stress, and current chemotherapy and radiation treatments derive their cytotoxic effects from increasing oxidative stress [50]. Due to their double bond structure, PUFAs and their metabolic products have an increased susceptibility to oxidation. Lipid peroxidation products have been shown to cause cell cycle arrest and induce tumour cell death [76]. There is conflicting research suggesting that CLA either augments or reduces oxidative stress in breast cancer cells. Albright et al. reported a preferential increase in oxidative stress and a resulting inhibition of the cell cycle with $50 \mu \mathrm{M}$ of a CLA mixture in MCF-7 cells as compared to normal mammary epithelial ductal cells (MCF-10A) [50]. CLA treatment has also been shown to increase the activity of superoxide dismutase, catalase and glutathione peroxidase (protective enzymes against oxidative stress) [77], as well as increase the lipid peroxidation product 8-epi-PG (prostaglandin)F $2 \alpha$ [78]. These findings support the argument that CLA induces oxidative stress. In contrast, a one month CLA feeding trial in Sprague-Dawley rats showed that a CLA mixture reduced the presence of lipid peroxidation products in the mammary gland [18]. Research into other models of cancer also report conflicting results regarding CLA's potential role in oxidative stress [10, 79]. Some believe that CLA's interference with the metabolism of other fatty acids, such as linoleic acid (LA, which may be more susceptible to peroxidation) is the pathway by which it has an effect on oxidation [24].

\section{Changes to Cell Membrane Structure and Function}

PUFAs with cis-double bonds are believed to impact the physical properties of the cell membrane due to their 'kinked' structure, which allows for less tight packing of surrounding fatty acyl groups [80]. In contrast, the incorporation of the straighter trans fatty acids into membranes has been shown to decrease membrane fluidity and interfere with the function of membrane receptors [81-83]. Changes to the dietary fatty acid composition of the plasma membrane and subsequently the physical structure have been shown to alter lipid-protein interactions, affect ion transporters, receptors, signal transducers and enzymes [80, 84-86]. The two most commonly investigated CLA isomers, c9,t11 and t10,c12, contain both a cis and a trans bond. When provided in the diet or cell culture medium, CLA isomers are readily incorporated into the phospholipids of tumour cell membranes $[87,88]$. The trans-bond in the major CLA isomers has the potential to alter the physical structure of the membrane and this could then alter the function of important proteins and signals that are located or generated from the plasma membrane. Recently it was demonstrated that incubation with CLA was associated with a reduction in the expression of the membrane receptor HER2 in the HER-2 expressing breast cancer cell line SKBr3 [55] and incorporation of both of the major isomers of CLA in the membrane phospholipids was associated with a reduction in the amount of the IGF-1 receptor in MCF-7 cells [88].

The impact of CLA incorporation into membranes on essential fatty acid metabolism and the subsequent production of eicosanoids has been studied. Due to the chemical similarities between LA and CLA, it was initially hypothesized that CLA may compete with the incorporation or metabolism of LA in membrane phospholipids and thereby interfere with the synthesis of the essential fatty acid arachidonic acid (AA, C20:4n-6) [89]. AA is a substrate for eicosanoids: prostaglandins are produced from AA via cycloxygenase enzymes and leukotrienes are produced via lipoxygenase enzymes. Eicosanoids are hormone-like compounds that exert many cellular functions and have been demonstrated to be involved in cell growth and apoptosis in human breast cancer [90]. Neither major isomer of CLA, nor a CLA mixture, appears to decrease the incorporation of LA in membrane phospholipids [21, 24, 91, 92]. However, CLA has been reported to interfere with essential fatty acid metabolism. Both a CLA mixture (c9,t11 and t10,c12) and/or t10,c12 CLA alone reduce the elongation and desaturation products of LA, most importantly AA [24, 92]. Consistent with this, CLA has been reported to interfere with the production of $\mathrm{PGE}_{2}$ as well as 5-HETE, an important substrate of the lipoxygenase pathway $[55,87,93]$. The distribution of fatty acids among the different phospholipid classes of the plasma membrane influences eicosanoid production. Phospholipase A2 preferentially detaches fatty acids from phosphatidylcholine (PC), making PC the preferential source of AA for eicosanoid synthesis. Miller et al. [94] showed that CLA decreases the amount of AA stored in PC and increases it in phosphatidylethanolamine (PE) along with a subsequent decrease in the production of $\mathrm{PGE}_{2}$. Although these researchers have reported that CLA may interfere with essential fatty acid metabolism, the more effective isomer is still controversial $[92,94]$.

Interestingly, a recent study reported that either a mixture of CLA isomers or t10,c12 CLA was effective at reducing the transcriptional activity of the cyclooxygenase-2 (COX-2) promoter in MCF-7 cells (the c9,t11 CLA isomer was less effective), suggesting an alternative mechanism by which CLA may interfere with eicosanoid metabolism [95]. Additionally, a recent study suggests that a mixture of CLA isomers decreased S14 and fatty acid synthetase in T47D breast 
cancer cells [96], suggesting that CLA also interferes with fatty acid synthesis in these cancer cells.

\section{Interference with Growth Factor Receptors/Signaling Pathways}

The insulin-like growth factor (IGF) and epidermal growth factor (EGF) are proteins that stimulate cell proliferation and inhibit apoptosis. Their receptors and/or signaling pathways are often up-regulated in cancer [97]. Some current chemotherapy treatments are designed, or are in the process of being designed, to interfere with growth factor promotion of cell growth. For example, Trastuzumab (Herceptin), blocks the function of the Her2/neu/ErbB2 receptor (part of the EGF family), which is often overexpressed in breast cancers [97]. Recently, it was demonstrated that incubation with $\mathrm{t} 10, \mathrm{c} 12$ CLA reduced HER2 expression in SKBr3 cells [55].

At this time, little is known about the effects of CLA on EGF signaling. Recently we demonstrated that incubation with either major isomer of CLA decreased the cellular concentrations of IGF-1 in MCF-7 cells [88]. Only a small number of studies have investigated the effects of CLA on IGF-I signaling. In vitro, CLA interferes with IGF signaling in the HT-29 human colon cancer cell line [98]. IGF-1 is essential for pubertal mammary development of the terminal end buds $[72,99]$. Studies using rodent mammary cancer models have shown that CLA interferes with terminal end bud development [100], providing preliminary support for an inhibitory effect of CLA on IGF signaling. Since then, CLA has been reported to interfere with insulin-stimulated proliferation of MCF-7 cells in vitro, with t10,c12 CLA showing greater inhibition than $\mathrm{c} 9, \mathrm{t} 11$ CLA or a CLA mixture [101]. Studies from our own laboratory showed that t10,c12 CLA (but not c9,t11 CLA) reduced the levels of phosphorylated IGF-1 receptor in MCF-7 cells [88]. In contrast to the cell culture studies, Meng et al. recently reported the results of an animal feeding study in which t10,c12 CLA, when fed to female transgenic mice bearing ErbB2-overexpressing mammary tumours, increased mammary tumour growth and increased phosphorylation of the IGF-IR/IR and its downstream targets PI3K, Akt, MEK, and ERK [102]. The CLA-induced stimulation of tumour growth in this model is consistent with a previous report by this group [43]. It is not clear whether the conflicting reports between in vitro and in vivo studies are related to differences in tumour model or to the contribution of the tumour microenvironment in vivo, but clearly further research is warranted.

\section{SUMMARY}

The interest and evidence that CLA may become a future neutraceutical treatment for the treatment and prevention of cancer is rapidly growing. The evidence is summarized in Tables 1-3. Basic research into the mechanisms behind the anti-carcinogenic effect of CLA offers insight into its modifications to cellular function and the surrounding stromal environment. From a review of the current literature, it can be concluded that CLA has the potential to target multiple characteristics or hallmarks of cancer such as apoptosis, angiogenesis and sensitivity to growth signals. The convincing anticancer effects of both major CLA isomers that have been observed in human tumour cell lines and animal models of cancer provide preliminary evidence to suggest an application in humans. Dr. T.K. Basu so elegantly demonstrated during his career that one needs to demonstrate an effect first in vitro/in situ $[103,104]$, then in the appropriate animal models [3-5] and finally demonstrate efficacy in well designed human trials [105-107]. Thus, before trials can be proposed to test efficacy of CLA, it is necessary to elucidate the biological mechanism(s) that might explain the antitumour effects of the CLA isomers. This possible mechanism would need to be novel and/or complementary to current therapies available for the treatment of breast cancer. More animal studies are required before the progression to human clinical trials to further establish the specificity of CLA to mammary cancer and effectiveness of a plausible intake of CLA for human trials. A greater understanding of CLA's mechanism of action will support the development of clinical trials to evaluate the potential effectiveness of CLA in the treatment of breast cancer.

\section{ACKNOWLEDGEMENTS}

D. Amaru was a recipient of a Natural Sciences and Engineering Research Council of Canada Scholarship (NSERC). This research is part of a project to C. Field from the Canadian Institute of Health Research (CIHR).

\section{CONFLICT OF INTEREST}

There is no conflict of interest by any of the authors

\begin{tabular}{|c|c|c|}
\hline \multicolumn{3}{|c|}{ ABBREVIATIONS } \\
\hline AA & $=$ & Arachidonic acid \\
\hline CLA & $=$ & Conjugated linoleic acid \\
\hline $\mathrm{COX}-2$ & $=$ & Cyclooxygenase- 2 \\
\hline ECM & $=$ & Extracellular matrix \\
\hline EGF & $=$ & Epidermal growth factor \\
\hline IGF & $=$ & Insulin-like growth factor \\
\hline LA & $=$ & Linoleic acid \\
\hline $\mathrm{PC}$ & $=$ & Phosphatidylcholine \\
\hline $\mathrm{PE}$ & $=$ & Phosphatidylethanolamine \\
\hline PG & $=$ & Prostaglandin \\
\hline PPAR & $=$ & Peroxisome proliferator-activated receptor \\
\hline PUFA & $=$ & Polyunsaturated fatty acid \\
\hline VEGF & $=$ & Vascular endothelial growth factors \\
\hline
\end{tabular}

\section{REFERENCES}

[1] Basu TK, Mann S. Vitamin B-6 normalizes the altered sulfur amino acid status of rats fed diets containing pharmacological levels of niacin without reducing niacin's hypolipidemic effects. J Nutr 1997; 127: 117-21.

[2] Basu TK, Makhani N, Sedgwick G. Niacin (nicotinic acid) in nonphysiological doses causes hyperhomocysteineaemia in SpragueDawley rats. Br J Nutr 2002; 87: 115-9.

[3] Goel V, Cheema SK, Agellon LB, Ooraikul B, Basu TK. Dietary rhubarb (Rheum rhaponticum) stalk fibre stimulates cholesterol 7 alpha-hydroxylase gene expression and bile acid excretion in cholesterol-fed C57BL/6J mice. Br J Nutr 1999; 81: 65-71.

[4] Goel V, Chang C, Slama JV, et al. Alkylamides of Echinacea purpurea stimulate alveolar macrophage function in normal rats. Int Immunopharmacol 2002; 2: 381-7. 
[5] Srichamroen A, Field CJ, Thomson AB, Basu TK. The modifying effects of galactomannan from Canadian-grown fenugreek (Trigonella foenum-graecum L.) on the glycemic and lipidemic status in rats. J Clin Biochem Nutr 2008; 43: 167-74.

[6] Doll R, Peto R. The causes of cancer: quantitative estimates of avoidable risks of cancer in the United States today. J Natl Cancer Inst 1981; 66: 1191-308.

[7] Holmes MD, Willett WC. Does diet affect breast cancer risk? Breast Cancer Res 2004; 6: 170-8.

[8] Buell P. Changing incidence of breast cancer in Japanese-American women. J Natl Cancer Inst 1973; 51: 1479-83.

[9] Pariza MW, Ashoor SH, Chu FS, Lund DB. Effects of temperature and time on mutagen formation in pan-fried hamburger. Cancer Lett 1979; 7: 63-9.

[10] Ha YL, Grimm NK, Pariza MW. Anticarcinogens from fried ground beef: heat-altered derivatives of linoleic acid. Carcinogenesis $1987 ; 8$ : 1881-7.

[11] Sebedio JL, Gnaedig S, Chardigny JM. Recent advances in conjugated linoleic acid research. Curr Opin Clin Nutr Metab Care 1999; 2: 499-506.

[12] Dhiman TR, Nam SH, Ure AL. Factors affecting conjugated linoleic acid content in milk and meat. Crit Rev Food Sci Nutr 2005; 45: 463-82.

[13] Ens JG, Ma DW, Cole KS, Field CJ, Clandinin MT. An assessment of c9,t11 linoleic acid intake in a small group of young Canadians. Nutr Res 2001; 21: 955-60.

[14] Jiang J, Wolk A, Vessby B. Relation between the intake of milk fat and the occurrence of conjugated linoleic acid in human adipose tissue. Am J Clin Nutr 1999; 70: 21-7.

[15] Ritzenthaler KL, McGuire MK, Falen R, Shultz TD, Dasgupta N, McGuire MA. Estimation of conjugated linoleic acid intake by written dietary assessment methodologies underestimates actual intake evaluated by food duplicate methodology. J Nutr 2001; 131 : 1548-54.

[16] Fritsche, Steinhart H. Amounts of conjugated linoleic acid (CLA) in German Foods and evaluation of daily intake. A Lebensm Unters Forsch A 1998; 206: 77-82.

[17] Lock AL, Bauman DE. Modifying milk fat composition of dairy cows to enhance fatty acids beneficial to human health. Lipids 2004; 39: 1197-206.

[18] Ip C, Chin SF, Scimeca JA, Pariza MW. Mammary cancer prevention by conjugated dienoic derivative of linoleic acid. Cancer Res 1991; 51: 6118-24.

[19] Ip C, Scimeca JA, Thompson HJ. Conjugated linoleic acid. A powerful anticarcinogen from animal fat sources. Cancer 1994; 74 : $1050-4$.

[20] Ip C, Scimeca JA, Thompson H. Effect of timing and duration of dietary conjugated linoleic acid on mammary cancer prevention. Nutr Cancer 1995; 24: 241-7.

[21] Ip C, Briggs SP, Haegele AD, Thompson HJ, Storkson J, Scimeca JA. The efficacy of conjugated linoleic acid in mammary cancer prevention is independent of the level or type of fat in the diet. Carcinogenesis 1996; 17: 1045-50.

[22] Ip C, Jiang C, Thompson HJ, Scimeca JA. Retention of conjugated linoleic acid in the mammary gland is associated with tumor inhibition during the post-initiation phase of carcinogenesis. Carcinogenesis 1997; 18: 755-9.

[23] Thompson H, Zhu Z, Banni S, Darcy K, Loftus T, Ip C. Morphological and biochemical status of the mammary gland as influenced by conjugated linoleic acid: implication for a reduction in mammary cancer risk. Cancer Res 1997; 57: 5067-72.

[24] Banni S, Angioni E, Casu V, et al. Decrease in linoleic acid metabolites as a potential mechanism in cancer risk reduction by conjugated linoleic acid. Carcinogenesis 1999; 20: 1019-24.

[25] Ip C, Banni S, Angioni E, et al. Conjugated linoleic acid-enriched butter fat alters mammary gland morphogenesis and reduces cancer risk in rats. J Nutr 1999; 129: 2135-2142.

[26] Ip C, Ip MM, Loftus T, Shoemaker S, Shea-Eaton W. Induction of apoptosis by conjugated linoleic acid in cultured mammary tumor cells and premalignant lesions of the rat mammary gland. Cancer Epidemiol Biomarkers Prev 2000; 9: 689-96.

[27] Kimoto N, Hirose M, Futakuchi M, Iwata T, Kasai M, Shirai T. Site-dependent modulating effects of conjugated fatty acids from safflower oil in a rat two-stage carcinogenesis model in female Sprague-Dawley rats. Cancer Lett 2001; 168: 15-21.
[28] Futakuchi M, Cheng JL, Hirose M, et al. Inhibition of conjugated fatty acids derived from safflower or perilla oil of induction and development of mammary tumors in rats induced by 2-amino-1methyl-6-phenylimidazo[4,5-b]pyridine (PhIP). Cancer Lett 2002; 178: 131-9.

[29] Banni S, Angioni E, Murru E, et al. Vaccenic acid feeding increases tissue levels of conjugated linoleic acid and suppresses development of premalignant lesions in rat mammary gland. Nutr Cancer 2001; 41: 91-7.

[30] Ip C, Dong Y, Ip MM, et al. Conjugated linoleic acid isomers and mammary cancer prevention. Nutr Cancer 2002; 43: 52-8.

[31] Cheng JL, Futakuchi M, Ogawa K, et al. Dose response study of conjugated fatty acid derived from safflower oil on mammary and colon carcinogenesis pretreated with 7,12-dimethylbenz[a] anthracene (DMBA) and 1,2-dimethylhydrazine (DMH) in female Sprague-Dawley rats. Cancer Lett 2003; 196: 161-8.

[32] Lavillonniere F, Chajes V, Martin JC, Sebedio JL, Lhuillery C, Bougnoux P. Dietary purified cis-9,trans-11 conjugated linoleic acid isomer has anticarcinogenic properties in chemically induced mammary tumors in rats. Nutr Cancer 2003; 45: 190-4.

[33] Corl BA, Barbano DM, Bauman DE, Ip C. cis-9, trans-11 CLA derived endogenously from trans-11 18:1 reduces cancer risk in rats. J Nutr 2003; 133: 2893-900.

[34] Lock AL, Corl BA, Barbano DM, Bauman DE, Ip C. The anticarcinogenic effect of trans-11 18:1 is dependent on its conversion to cis-9, trans-11 CLA by delta9-desaturase in rats. J Nutr 2004; 134: 2698-704.

[35] Visonneau S, Cesano A, Tepper SA, Scimeca JA, Santoli D, Kritchevsky D. Conjugated linoleic acid suppresses the growth of human breast adenocarcinoma cells in SCID mice. Anticancer Res 1997; 17: 969-73.

[36] Hubbard NE, Lim D, Summers L, Erickson KL. Reduction of murine mammary tumor metastasis by conjugated linoleic acid. Cancer Lett 2000; 150: 93-100.

[37] Masso-Welch PA, Zangani D, Ip C, et al. Inhibition of angiogenesis by the cancer chemopreventive agent conjugated linoleic acid. Cancer Res 2002; 62: 4383-9.

[38] Hubbard NE, Lim D, Erickson KL. Effect of separate conjugated linoleic acid isomers on murine mammary tumorigenesis. Cancer Lett 2003; 190: 13-9.

[39] Masso-Welch PA, Zangani D, Ip C, et al. Isomers of conjugated linoleic acid differ in their effects on angiogenesis and survival of mouse mammary adipose vasculature. J Nutr 2004; 134: 299-307.

[40] Dauchy RT, Dauchy EM, Sauer LA, et al. Differential inhibition of fatty acid transport in tissue-isolated steroid receptor negative human breast cancer xenografts perfused in situ with isomers of conjugated linoleic acid. Cancer Lett 2004; 209: 7-15.

[41] Hubbard NE, Lim D, Erickson KL. Beef tallow increases the potency of conjugated linoleic acid in the reduction of mouse mammary tumor metastasis. J Nutr 2006; 136: 88-93.

[42] Wong MW, Chew BP, Wong TS, Hosick HL, Boylston TD, Shultz TD. Effects of dietary conjugated linoleic acid on lymphocyte function and growth of mammary tumors in mice. Anticancer Res 1997; 17: 987-93.

[43] Ip MM, McGee SO, Masso-Welch PA, et al. The t10,c12 isomer of conjugated linoleic acid stimulates mammary tumorigenesis in transgenic mice over-expressing erbB2 in the mammary epithelium. Carcinogenesis 2007; 28: 1269-76.

[44] House RL, Cassady JP, Eisen EJ, McIntosh MK, Odle J. Conjugated linoleic acid evokes de-lipidation through the regulation of genes controlling lipid metabolism in adipose and liver tissue. Obes Rev 2005; 6: 247-58.

[45] Wang LS, Huang YW, Sugimoto Y, et al. Effects of human breast stromal cells on conjugated linoleic acid (CLA) modulated vascular endothelial growth factor-A (VEGF-A) expression in MCF-7 cells. Anticancer Res 2005; 25: 4061-8.

[46] DesBordes C, Lea MA. Effects of C18 fatty acid isomers on DNA synthesis in hepatoma and breast cancer cells. Anticancer Res 1995; 15: 2017-21.

[47] Durgam VR, Fernandes G. The growth inhibitory effect of conjugated linoleic acid on MCF-7 cells is related to estrogen response system. Cancer Lett 1997; 116: 121-30.

[48] Kemp MQ, Jeffy BD, Romagnolo DF. Conjugated linoleic acid inhibits cell proliferation through a p53-dependent mechanism: effects on the expression of G1-restriction points in breast and colon cancer cells. J Nutr 2003; 133: 3670-7. 
[49] Majumder B, Wahle KW, Moir S, et al. Conjugated linoleic acids (CLAs) regulate the expression of key apoptotic genes in human breast cancer cells. FASEB J 2002; 16: 1447-9.

[50] Albright CD, Klem E, Shah AA, Gallagher P. Breast cancer celltargeted oxidative stress: enhancement of cancer cell uptake of conjugated linoleic acid, activation of p53, and inhibition of proliferation. Exp Mol Pathol 2005; 79: 118-25.

[51] Seo JH, Moon HS, Kim IY, et al. PEGylated conjugated linoleic acid stimulation of apoptosis via a p53-mediated signaling pathway in MCF-7 breast cancer cells. Eur J Pharm Biopharm 2008; 70: 621-6.

[52] Miglietta A, Bozzo F, Bocca C, et al. Conjugated linoleic acid induces apoptosis in MDA-MB-231 breast cancer cells through ERK/MAPK signalling and mitochondrial pathway. Cancer Lett 2006; 234: 149-57.

[53] Ou L, Wu Y, Ip C, Meng X, Hsu YC, Ip MM. Apoptosis induced by t10,c12-conjugated linoleic acid is mediated by an atypical endoplasmic reticulum stress response. J Lipid Res 2008; 49: 98594.

[54] Islam MA, Kim YS, Jang WJ, et al. A mixture of trans, trans conjugated linoleic acid induces apoptosis in MCF-7 human breast cancer cells with reciprocal expression of Bax and Bcl-2. J Agric Food Chem 2008; 56: 5970-6.

[55] Flowers M, Thompson PA. t10c12 conjugated linoleic acid suppresses HER2 protein and enhances apoptosis in SKBr3 breast cancer cells: possible role of COX2. PLoS One 2009; 4: e5342

[56] Wang LS, Huang YW, Liu S, Yan P, Lin YC. Conjugated linoleic acid induces apoptosis through estrogen receptor alpha in human breast tissue. BMC Cancer 2008; 8: 208

[57] Ou L, Ip C, Lisafeld B, Ip MM. Conjugated linoleic acid induces apoptosis of murine mammary tumor cells via Bcl-2 loss. Biochem Biophys Res Commun 2007; 356: 1044-9.

[58] Wang T, Xu J, Yu X, Yang R, Han ZC. Peroxisome proliferatoractivated receptor gamma in malignant diseases. Crit Rev Oncol Hematol 2006; 58: 1-14.

[59] Mueller E, Sarraf P, Tontonoz P, et al. Terminal differentiation of human breast cancer through PPAR gamma. Mol Cell 1998; 1: 465-70.

[60] Kim KY, Kim SS, Cheon HG. Differential anti-proliferative actions of peroxisome proliferator-activated receptor-gamma agonists in MCF-7 breast cancer cells. Biochem Pharmacol 2006; 72: 530-40.

[61] Hollingshead HE, Killins RL, Borland MG, et al. Peroxisome proliferator-activated receptor- $\{$ beta $\} /\{$ delta $\}$ (PPAR $\{$ beta $\} /\{$ delta $\}$ ) ligands do not potentiate growth of human cancer cell lines. Carcinogenesis 2007; 28: 2641-9.

[62] Stephen RL, Gustafsson MC, Jarvis M, et al. Activation of peroxisome proliferator-activated receptor delta stimulates the proliferation of human breast and prostate cancer cell lines. Cancer Res 2004; 64: 3162-70.

[63] Crowe DL, Chandraratna RA. A retinoid X receptor (RXR)selective retinoid reveals that RXR-alpha is potentially a therapeutic target in breast cancer cell lines, and that it potentiates antiproliferative and apoptotic responses to peroxisome proliferator-activated receptor ligands. Breast Cancer Res 2004; 6: R546-R555.

[64] Murakami K, Ide T, Suzuki M, Mochizuki T, Kadowaki T. Evidence for direct binding of fatty acids and eicosanoids to human peroxisome proliferators-activated receptor alpha. Biochem Biophys Res Commun 1999; 260: 609-13.

[65] Xu HE, Lambert MH, Montana VG, et al. Molecular recognition of fatty acids by peroxisome proliferator-activated receptors. Mol Cell 1999; 3: 397-403.

[66] Kliewer SA, Lehmann JM, Willson TM. Orphan nuclear receptors: shifting endocrinology into reverse. Science 1999; 284: 75760.

[67] Maggiora M, Bologna M, Ceru MP, et al. An overview of the effect of linoleic and conjugated-linoleic acids on the growth of several human tumor cell lines. Int J Cancer 2004; 112: 909-19.

[68] Bocca C, Bozzo F, Francica S, Colombatto S, Miglietta A. Involvement of PPAR gamma and E-cadherin/beta-catenin pathway in the antiproliferative effect of conjugated linoleic acid in MCF-7 cells. Int J Cancer 2007; 121: 248-56.

[69] Tanmahasamut P, Liu J, Hendry LB, Sidell N. Conjugated linoleic acid blocks estrogen signaling in human breast cancer cells. J Nutr 2004; 134: 674-80.
[70] Mueller MM, Fusenig NE. Friends or foes - bipolar effects of the tumour stroma in cancer. Nat Rev Cancer 2004; 4: 839-49.

[71] Ip MM, Masso-Welch PA, Shoemaker SF, Shea-Eaton WK, Ip C. Conjugated linoleic acid inhibits proliferation and induces apoptosis of normal rat mammary epithelial cells in primary culture. Exp Cell Res 1999; 250: 22-34.

[72] Sternlicht MD. Key stages in mammary gland development: the cues that regulate ductal branching morphogenesis. Breast Cancer Res 2006; 8: 201

[73] Sikorski AM, Hebert N, Swain RA. Conjugated Linoleic Acid (CLA) inhibits new vessel growth in the mammalian brain. Brain Res 2008; 1213: 35-40.

[74] Hubbard NE, Lim D, Erickson KL. Conjugated linoleic acid alters matrix metalloproteinases of metastatic mouse mammary tumor cells. J Nutr 2007; 137: 1423-9.

[75] Soel SM, Choi OS, Bang MH, Yoon Park JH, Kim WK. Influence of conjugated linoleic acid isomers on the metastasis of colon cancer cells in vitro and in vivo. J Nutr Biochem 2007; 18: 650-7.

[76] Tang DG, La E, Kern J, Kehrer JP. Fatty acid oxidation and signaling in apoptosis. Biol Chem 2002; 383: 425-42.

[77] O'Shea M, Devery R, Lawless F, Murphy J, Stanton C. Milk fat conjugated linoleic acid (CLA) inhibits growth of human mammary MCF-7 cancer cells. Anticancer Res 2000; 20: 3591-601.

[78] Miller A, Stanton C, Murphy J, Devery R. Conjugated linoleic acid (CLA)-enriched milk fat inhibits growth and modulates CLAresponsive biomarkers in $\mathrm{MCF}-7$ and SW480 human cancer cell lines. Br J Nutr 2003; 90: 877-85.

[79] Igarashi M, Miyazawa $T$. The growth inhibitory effect of conjugated linoleic acid on a human hepatoma cell line, HepG2, is induced by a change in fatty acid metabolism, but not the facilitation of lipid peroxidation in the cells. Biochim Biophys Acta 2001; 1530: 162-71.

[80] Stubbs CD, Smith AD. The modification of mammalian membrane polyunsaturated fatty acid composition in relation to membrane fluidity and function. Biochim Biophys Acta 1984; 779: 89-137.

[81] Niu SL, Mitchell DC, Litman BJ. Trans fatty acid derived phospholipids show increased membrane cholesterol and reduced receptor activation as compared to their cis analogs. Biochemistry 2005; 44: 4458-65.

[82] Ibrahim A, Natrajan S, Ghafoorunissa R. Dietary trans-fatty acids alter adipocyte plasma membrane fatty acid composition and insulin sensitivity in rats. Metabolism 2005; 54: 240-6.

[83] Roach C, Feller SE, Ward JA, Shaikh SR, Zerouga M, Stillwell W. Comparison of cis and trans fatty acid containing phosphatidylcholines on membrane properties. Biochemistry 2004; 43: 6344 51 .

[84] Grimble RF, Tappia PS. Modulatory influence of unsaturated fatty acids on the biology of tumour necrosis factor-alpha. Biochem Soc Trans 1995; 23: 282-7.

[85] Jolly CA, Jiang YH, Chapkin RS, McMurray DN. Dietary (n-3) polyunsaturated fatty acids suppress murine lymphoproliferation, interleukin-2 secretion, and the formation of diacylglycerol and ceramide. J Nutr 1997; 127: 37-43.

[86] De Pablo MA, Varez de CG. Modulatory effects of dietary lipids on immune system functions. Immunol Cell Biol 2000; 78: 31-9.

[87] Ma DW, Field CJ, Clandinin MT. An enriched mixture of trans10,cis-12-CLA inhibits linoleic acid metabolism and PGE2 synthesis in MDA-MB-231 cells. Nutr Cancer 2002; 44: 203-12.

[88] Amaru DL, Field CJ. Conjugated linoleic acid decreases mcf-7 human breast cancer cell growth and insulin-like growth factor-1 receptor levels. Lipids 2009; 44: 449-58.

[89] Ha YL, Storkson J, Pariza MW. Inhibition of benzo(a)pyreneinduced mouse forestomach neoplasia by conjugated dienoic derivatives of linoleic acid. Cancer Res 1990; 50: 1097-101.

[90] Tong WG, Ding XZ, Adrian TE. The mechanisms of lipoxygenase inhibitor-induced apoptosis in human breast cancer cells. Biochem Biophys Res Commun 2002; 296: 942-8.

[91] Ip C. Review of the effects of trans fatty acids, oleic acid, n-3 polyunsaturated fatty acids, and conjugated linoleic acid on mammary carcinogenesis in animals. Am J Clin Nutr 1997; 66: $1523 \mathrm{~S}-9 \mathrm{~S}$.

[92] Ma DW, Field CJ, Clandinin MT. An enriched mixture of trans10,cis-12-CLA inhibits linoleic acid metabolism and PGE2 synthesis in MDA-MB-231 cells. Nutr Cancer 2002; 44: 203-12.

[93] Kim JH, Hubbard NE, Ziboh V, Erickson KL. Conjugated linoleic acid reduction of murine mammary tumor cell growth through 5- 
hydroxyeicosatetraenoic acid. Biochim Biophys Acta 2005; 1687: 103-109.

[94] Miller A, Stanton C, Devery R. Modulation of arachidonic acid distribution by conjugated linoleic acid isomers and linoleic acid in MCF-7 and SW480 cancer cells. Lipids 2001; 36: 1161-8.

[95] Degner SC, Kemp MQ, Hockings JK, Romagnolo DF. Cyclooxygenase-2 promoter activation by the aromatic hydrocarbon receptor in breast cancer mcf-7 cells: repressive effects of conjugated linoleic acid. Nutr Cancer 2007; 59: 248-57.

[96] Donnelly C, Olsen AM, Lewis LD, Eisenberg BL, Eastman A, Kinlaw WB. Conjugated linoleic acid (CLA) inhibits expression of the Spot 14 (THRSP) and fatty acid synthase genes and impairs the growth of human breast cancer and liposarcoma cells. Nutr Cancer 2009; 61: 114-22.

[97] Nahta R, Hortobagyi GN, Esteva FJ. Growth factor receptors in breast cancer: potential for therapeutic intervention. Oncologist 2003; 8: 5-17.

[98] Kim EJ, Kang IJ, Cho HJ, Kim WK, Ha YL, Park JH. Conjugated linoleic acid downregulates insulin-like growth factor-I receptor levels in HT-29 human colon cancer cells. J Nutr 2003; 133: 267581.

[99] Kleinberg DL, Feldman M, Ruan W. IGF-I: an essential factor in terminal end bud formation and ductal morphogenesis. J Mammary Gland Biol Neoplasia 2000; 5: 7-17.

[100] Ip C, Singh M, Thompson HJ, Scimeca JA. Conjugated linoleic acid suppresses mammary carcinogenesis and proliferative activity of the mammary gland in the rat. Cancer Res 1994; 54: 1212-5.

[101] Chujo H, Yamasaki M, Nou S, Koyanagi N, Tachibana H, Yamada $\mathrm{K}$. Effect of conjugated linoleic acid isomers on growth factorinduced proliferation of human breast cancer cells. Cancer Lett 2003; 202: 81-7.

[102] Meng X, Shoemaker SF, McGee SO, Ip MM. t10,c12-Conjugated linoleic acid stimulates mammary tumor progression in Her2/ErbB2 mice through activation of both proliferative and survival pathways. Carcinogenesis 2008; 29: 1013-21.

[103] Ziccarelli VE, Basu TK. An in vivo study of the antioxidant potentials of a plant food concentrate. J Am Coll Nutr 2003; 22: 277-82.

[104] Wang M, Guilbert LJ, Li J, et al. A proprietary extract from North American ginseng (Panax quinquefolium) enhances IL-2 and IFNgamma productions in murine spleen cells induced by Con-A. Int Immunopharmacol 2004; 4: 311-5.

[105] Predy GN, Goel V, Lovlin R, Donner A, Stitt L, Basu TK. Efficacy of an extract of North American ginseng containing poly-furanosylpyranosyl-saccharides for preventing upper respiratory tract infections: a randomized controlled trial. CMAJ 2005; 173: 1043-8.

[106] Goel V, Lovlin R, Chang C, et al. A proprietary extract from the echinacea plant (Echinacea purpurea) enhances systemic immune response during a common cold. Phytother Res 2005; 19: 689-94.

[107] Goel V, Ooraikul B, Basu TK. Cholesterol lowering effects of rhubarb stalk fiber in hypercholesterolemic men. J Am Coll Nutr 1997; 16: 600-4.

[108] Aro A, Mannisto S, Salminen I, Ovaskainen ML, Kataja V, Uusitupa M. Inverse association between dietary and serum conjugated linoleic acid and risk of breast cancer in postmenopausal women. Nutr Cancer 2000; 38: 151-7.

[109] Voorrips LE, Brants HA, Kardinaal AF, Hiddink GJ, Van den Brandt PA, Goldbohm RA. Intake of conjugated linoleic acid, fat, and other fatty acids in relation to postmenopausal breast cancer: the Netherlands Cohort Study on Diet and Cancer. Am J Clin Nutr 2002; 76: 873-82.

[110] McCann SE, Ip C, Ip MM, et al. Dietary intake of conjugated linoleic acids and risk of premenopausal and postmenopausal breast cancer, Western New York Exposures and Breast Cancer Study (WEB Study). Cancer Epidemiol Biomarkers Prev 2004; 13: 14804.
[111] Chajes V, Lavillonniere F, Maillard V, et al. Conjugated linoleic acid content in breast adipose tissue of breast cancer patients and the risk of metastasis. Nutr Cancer 2003; 45: 17-23.

[112] Larsson SC, Bergkvist L, Wolk A. Conjugated linoleic acid intake and breast cancer risk in a prospective cohort of Swedish Women. Am J Clin Nutr 2009; 90: 556-60.

[113] Josyula S, He YH, Ruch RJ, Schut HA. Inhibition of DNA adduct formation of PhIP in female F344 rats by dietary conjugated linoleic acid. Nutr Cancer 1998; 32: 132-8.

[114] Shultz TD, Chew BP, Seaman WR, Luedecke LO. Inhibitory effect of conjugated dienoic derivatives of linoleic acid and beta-carotene on the in vitro growth of human cancer cells. Cancer Lett 1992; 63: 125-33.

[115] Shultz TD, Chew BP, Seaman WR. Differential stimulatory and inhibitory responses of human MCF-7 breast cancer cells to linoleic acid and conjugated linoleic acid in culture. Anticancer Res 1992; 12: 2143-5.

[116] Cunningham DC, Harrison LY, Shultz TD. Proliferative responses of normal human mammary and MCF-7 breast cancer cells to linoleic acid, conjugated linoleic acid and eicosanoid synthesis inhibitors in culture. Anticancer Res 1997; 17: 197-203.

[117] O'Shea M, Stanton C, Devery R. Antioxidant enzyme defence responses of human MCF-7 and SW480 cancer cells to conjugated linoleic acid. Anticancer Res 1999; 19: 1953-9.

[118] Park Y, Allen KG, Shultz TD. Modulation of MCF-7 breast cancer cell signal transduction by linoleic acid and conjugated linoleic acid in culture. Anticancer Res 2000; 20: 669-76.

[119] Choi Y, Park Y, Storkson JM, Pariza MW, Ntambi JM. Inhibition of stearoyl-CoA desaturase activity by the cis- 9 , trans-11 isomer and the trans-10,cis-12 isomer of conjugated linoleic acid in MDAMB-231 and MCF-7 human breast cancer cells. Biochem Biophys Res Commun 2002; 294: 785-90.

[120] Oku H, Wongtangtintharn S, Iwasaki H, Toda T. Conjugated linoleic acid (CLA) inhibits fatty acid synthetase activity in vitro. Biosci Biotechnol Biochem 2003; 67: 1584-6.

[121] Liu J, Sidell N. Anti-estrogenic Effects of Conjugated Linoleic Acid through Modulation of Estrogen Receptor Phosphorylation. Breast Cancer Res Treat 2005; 94: 161-9.

[122] Wang LS, Huang YW, Sugimoto Y, et al. Conjugated linoleic acid (CLA) up-regulates the estrogen-regulated cancer suppressor gene, protein tyrosine phosphatase gamma (PTPgama), in human breast cells. Anticancer Res 2006; 26: 27-34.

[123] Degner SC, Kemp MQ, Bowden GT, Romagnolo DF. Conjugated linoleic acid attenuates cyclooxygenase-2 transcriptional activity via an anti-AP-1 mechanism in MCF-7 breast cancer cells. J Nutr 2006; 136: 421-7.

[124] De la Torre A, Debiton E, Juaneda P, et al. Beef conjugated linoleic acid isomers reduce human cancer cell growth even when associated with other beef fatty acids. Br J Nutr 2006; 95 : 346-52.

[125] Miglietta A, Bozzo F, Gabriel L, Bocca C, Canuto RA. Extracellular signal-regulated kinase $1 / 2$ and protein phosphatase $2 \mathrm{~A}$ are involved in the antiproliferative activity of conjugated linoleic acid in MCF-7 cells. Br J Nutr 2006; 96: 22-7.

[126] Miglietta A, Bozzo F, Bocca C, et al. Conjugated linoleic acid induces apoptosis in MDA-MB-231 breast cancer cells through ERK/MAPK signalling and mitochondrial pathway. Cancer Lett 2006; 234: 149-57.

[127] Guo DD, Moon HS, Arote R, et al. Enhanced anticancer effect of conjugated linoleic acid by conjugation with Pluronic F127 on MCF-7 breast cancer cells. Cancer Lett 2007; 254: 244-54.

[128] Fite A, Goua M, Wahle KW, Schofield AC, Hutcheon AW, Heys SD. Potentiation of the anti-tumour effect of docetaxel by conjugated linoleic acids (CLAs) in breast cancer cells in vitro. Prostaglandins Leukot Essent Fatty Acids 2007; 77: 87-96. 